\title{
A HISTORY OF FORENSIC MEDICINE IN CHINA
}

\author{
by \\ LU GWEI-DJEN AND JOSEPH NEEDHAM*
}

\section{INTRODUCTION}

From the very dawn of civilization, as soon as any ethical conceptions of justice began to be entertained, it must have been incumbent on magistrates and juristic officials everywhere to try to differentiate between accidental death, murder, and suicide. Soon other, similar questions began to arise as well, questions concerned with poisoning, wounding, arson, virginity, miscarriage and the like. Did a man drown by being pushed into the water, or was he already dead when he was thrown in; did he die when his house burned down around him, or was he murdered first? All this comes under the head of what is called forensic medicine, medical jurisprudence, medico-legal evidence, and the relative participation of jurists and physicians in developing it is a very interesting story. The advances of anatomy, physiology and pathology evidently bore very markedly on the subject.

Broadly speaking, the physicians tended to come into the field, writing learned treatises on all these topics at the time of the Scientific Revolution in Europe, in the days of Galileo and Vesalius when distinctively modern science was born. Later on we shall look at the history of this genre of writing in more detail, and yet we shall have to celebrate as our focal point here the greatest work of all the Middle Ages anywhere on forensic medicine, namely the Hsi Yuan Chi Lu [1] (The Washing Away of Unjust Imputations, or Wrongs), written not by a scholar-physician but by a jurist, Sung Tzhu [2], in AD 1247, during the Southern Sung period. As we shall see, however, his medical knowledge was quite considerable. There is no clear evidence that such knowledge was officially made use of before his time in establishing proof in courts of law, either in ancient Egypt, Babylonia, or Greece; yet the Hippocratic Corpus does discuss several medico-legal questions. Such matters as the relative fatality of wounds in different parts of the body, the possibility of super-foetation, the average duration of pregnancy, the viability of embryos before full term, and malingering, all of which are dealt with in the Corpus, must have come before the courts of law from time to time.

\footnotetext{
* Lu Gwei-Djen, PhD, Fellow of Robinson College, Cambridge, and Associate Director, Needham Research Institute; Joseph Needham, FRS, FBA, Hon. FRCP, Fellow of Gonville and Caius College, Cambridge, and Director, Needham Research Institute (East Asian History of Science Library), 8 Sylvester Road, Cambridge CB3 9AF.

Notes: Numbers in square brackets after transliterations from Chinese (e.g. 'Hsi Yuan Chi Lu [1]') refer to the Chinese characters. Full bibliographic information for references cited is given in the 'List of Western References;' 'List of modern Chinese and Japanese references' (italic numerals); as well as the 'List of old Chinese references.' The reference citation system is in accordance with that used in 'Science and Civilisation in China.'
} 


\section{Lu Gwei-Djen and Joseph Needham}

Nor do physicians appear to have been summoned to give opinions on such cases in Roman times, though it seems that a medical expert, studying the twenty-three stab wounds in the body of Julius Caesar (died 44 BC), declared that only one, in the chest, was fatal. ${ }^{1}$ As long as so much magic and mystery were included in the science of medicine, it is perhaps not to be wondered at that courts of law were disinclined to lay much emphasis on what its practitioners said.

Nevertheless, this element was less prominent in Chinese medicine from the beginning. We have noted elsewhere ${ }^{2}$ that ancient Chinese medicine, as we see it in the lives and pronouncements of such men as I Ho [3], I Huan [4], Pien Chhio [5], and Shunyü I [6], was rational through and through. It may be true that the Yin and Yang, the five elements, the five solid viscera and the six hollow viscera, were all ideas not alignable with modern science, but that was quite natural for the time in which they were devised and used. The reluctance of the Chinese courts to solicit medical opinion must rather be assigned to some other cause. Chinese judges and juristic officials were always, it must be remembered, men of the scholarly or literati class, and therefore socially and intellectually separate from the practising physicians, whose duty consisted in curing the living. ${ }^{3}$ Hence in cases of wounding, the physicians were indeed called in. ${ }^{4}$ Humanistic education had looked askance at scientists and technicians for many centuries, but in the Northern Sung this can hardly have been the case, because many of the literati actively concerned themselves with the sciences and the technologies.

Nevertheless, the classical scholars from the beginning read many medical books, and often took up medicine to ease the old age of their parents. ${ }^{5}$ Similarly, a Sung scholar would often choose another scholar as his physician rather than one of the itinerant medical pedlars who wandered about the country. One can see therefore how the scholarly jurists felt they could get on well enough without the evidence of the professional physicians; ${ }^{6}$ though the latter were generally called in wherever there was the possibility of death from acupuncture or moxa, and their opinions might also be solicited in cases where death had occurred from illness.

As McKnight has said, ${ }^{7}$ it is really not clear why physicians were so infrequently consulted. Perhaps their relatively low social status militated against their use, but by the Nan Sung time, the government medical colleges were turning out some well-trained practitioners. It is true that the Chinese physicians lacked the guild

\footnotetext{
${ }^{1}$ Smith (1), p. 600 .

${ }^{2}$ Lu Gwei-Djen \& Needham (5), pp. 78ff., 113-14, 144; Needham \& Lu Gwei-Djen (8); Needham (64), pp. $265 f$ f.

${ }^{3}$ The officials had passed the government examinations, and had bureaucratic titles to which the physicians could not aspire. See particularly $\mathrm{Li}$ Thao (I), who shows how the doctors were ridiculed in popular plays. On the other hand, the scholar-physicians did not like to demean themselves by examining dead bodies along with the ostensors (see below); this is brought out by Chhen Khang-I (I), p. 3.

${ }^{4}$ See Chia Ching-Thao $(I)$, who has studied the historical division of duties between the physicians and the magistrate's ostensors.

${ }_{5}^{5}$ As the common saying has it, "wei jen tzu chê pu kho pu chih i" [9] ("no man can afford not to study medicine"). For example, Huangfu Mi [10], who wrote the Chen Chiu Chia I Ching [11] (Treatise on Acupuncture and Moxibustion) originally became interested in medicine because of the illness of his mother: see Lu Gwei-Djen \& Needham (5).

${ }^{6}$ Other reasons are hazarded by $S$. van der Sprenkel (1), p. 74.

${ }^{7}$ McKnight (1), pp. $26 \mathrm{ff}$.
} 


\section{$A$ history of forensic medicine in China}

organization of their European colleagues, and therefore any "cohesive organisational form" through which to press for a more active role in forensic assignments. But perhaps the best explanation, however, is that they were never really interested in such cases. Their expertise touched upon the care of the living, the cure of disease, the restoration to health; and they were never really interested in examining corpses to help to decide legal cases. As we shall see, apart from the judge himself, the only "expert" at most medieval Chinese inquests was the wu tso [7], or ostensor, a man of low social status and little education. As he was also often in his own time an undertaker, he may well have had considerable experience in handling corpses, but he had no medical training or interests. As for the "old woman" (tso pho [8] or wên pho [12]) who in medieval China assisted in the examination of female corpses, she was usually a midwife. In early Chhin times she had generally been a bondswoman (li chhen chhieh [13]). ${ }^{8}$

In due course we shall show that there was a long tradition in China of medico-legal books, interweaving with a related genre of legal case-books for the benefit of judges. Why should the Chinese have been so early in the codification of the procedures of forensic medicine? The answer is indeed an interesting one. After the end of the Warring States period, in the third century BC, Chinese civilization was never again an aristocratic military feudalism such as was characteristic of Europe until the Renaissance. On the contrary, it was what has been called "bureaucratic" feudalism, in which the whole empire was ruled by an imperial court acting through a vast array of officials in a civil service- the mandarinate if you like. It was a great bureaucratic society centuries before anything of the kind was known in Europe. ${ }^{9}$ To put it in a nutshell, one could say that the idea of the "carrière ouverte aux talents", the career open to every talented young man, was not a French discovery at all; it had been long preceded by the Chinese bureaucratic tradition. At all times, and particularly in the best periods, the officials were chosen, as we know, by the imperial examinations, which started in the first century BC.

In the Chinese system, civil law did not develop very effectively. Law was generally thought of as criminal law, and law was not estimated very highly by the philosophers. ${ }^{10}$ However, criminal law did indeed develop, although at no time was any distinction between the juridical and the administrative power made. This was rather like the system which prevailed, for example, in modern colonial Africa, where the District Officer was also the judge of first instance. There could be appeals to higher juridical authorities, but at no stage really in the pyramid of administration was there a fundamental distinction between juridical function and the administrative function.

\footnotetext{
${ }^{8}$ See Chia Ching-Thao \& Chang Wei-Fêng (1).

9 The roots went back, of course, to the Chou period and the feudal states, whose rulers had long depended on a class of official bureaucrats.

${ }^{10}$ For general disquisitions on Chinese law and its history, we must mention the books of Escarra (1); Chhü Thung-Tsu (1); S. van der Sprenkel (1); Bodde \& Morris (1). On Chhing law see Alabaster (1). There are also illuminating papers by Bodde $(26,29)$. We have touched upon the philosophy of law at several points in our consideration of human law and laws of nature in China and the West in, Joseph Needham, with the research assistance of Wang Ling, Science and civilisation in China [henceforth: SCC], vol. 2, History of scientific thought, Cambridge University Press, 1956, pp. 518ff. On the concept of law in general, see Hart (1).
} 
From this it is clear that the judge in medieval China had to be not only a judge but also the prosecutor, the defending counsel, the chief detective-superintendent, and a Sherlock Holmes as well. A tremendous amount of natural wisdom and deep insight into the motives of people came out in the process and got codified in due course. Any official, any member of the mandarinate, could be drafted into the position of judge, and specialize thereafter in juridical cases. This was in fact true of Sung Tzhu himself, renowned as a judge throughout subsequent Chinese history.

But still all this does not explain where the special passion for justice, the washing away of wrongs or unjust imputations, which evidently inspired Sung Tzhu and his predecessors and successors, came from. Here one always has to remember that while Chinese society was bureaucratic, it was also essentially Confucian, and that meant that it was dominated by an ethical system which neither had nor required supernatural sanctions. It was a this-worldly morality, springing from the believed fundamental nature of man himself, and all the more compulsive because it depended on no higher being. The scholars were rather sceptical and detached in matters of religion, however much the common people might run after Buddhist monks and Taoist priests; and what the scholars at their best responded to was a "moral imperative" defined two thousand years before Immanuel Kant. This may help us to understand why the clearing of the innocent, the comforting of widows and orphans, and the bringing of the cruel and violent to justice was such a consuming urge with men like Sung Tzhu [7] and all his predecessors, including Judge Ti and Judge Pao. Ti Jen-Chieh [14] (died AD 700) was a figure of the Thang dynasty who came down through the ages in song and story, and Pao Chhêng [15] (died AD 1062) was equally renowned in popular tradition. So also these considerations may go some way to explain why forensic medicine arose so early, perhaps earlier than in any other part of the world, in Chinese civilization.

\section{SUNG TZHU AND HIS TIMES}

Now a word or two about the life of Sung Tzhu. ${ }^{11} \mathrm{He}$ was born in AD 1181 into an unimpeachably official and Confucian family - his father had been a judge-and in his youth he was taught by Wu Chih [16], one of the followers of Chu Hsi [17] himself, that greatest of Neo-Confucian philosophers. ${ }^{12}$ In AD 1205, at the age of twenty, he entered the Imperial University, then under Chen Tê-Hsiu [18] who in due course praised him for his literary ability. Graduating chin shih [19] in 1217, he was appointed sheriff of a sub-prefecture in Chekiang, but as his father then died, he could not go to take up the post. In 1226, however, he became chu po [20], i.e. Registrar, at Hsin-fêng [21] in

\footnotetext{
${ }^{11}$ There are biographies of him by Chuko Chi (I); Jen An (l), pp. 68ff.; Yang Wên-Ju \& Li Pao-Hua (I); Kao Ming-Hsüan \& Sung Chih-Chhi (I); and H. Franke (19), vol. 3, p. 990. In recent times much has been written about this subject in Chinese literature, starting from Chhen Pang-Hsien (I), p. 189; and going on to Sung Ta-Jen (8), Shih Jo-Lin (I); Chhen Khang-I (I); Chang Hsien-Chê \& Tshai Kuei-Hua (I); and Miyashita Saburo (4). But since the Yuan edition of Sung Tzhu's Hsi Yuan Chi Lu was only made available in 1968, some of these authors had nothing but the Hsi Yuan Lu material at their disposal (see above). Of the biographies, only Sung Ta-Jen $(8)$ and Chang Hsien-Chê \& Tshai Kuei-Hua (l), so far as we know, are free from this criticism. Both contain a detailed chronology of his life.

${ }^{12}$ SCC, vol. 2, pp. 455ff.
} 


\section{$A$ history of forensic medicine in China}

Chiangsi, and during the ensuing years made a great name for himself by putting down peasant rebellions while at the same time meeting their root causes by distributing food from government granaries. In 1238 he was despatched to Nan-chien [22], where he found that the wealthy were hoarding a great deal of rice, so he classified the people into five groups, and relieved the extremities of the poorest by nationalizing the excesses of the richest. His first judicial post came in 1239 when he was appointed thi tien hsing yü [23] of Kuangtung; there he liberated many innocent prisoners and in eight months decided some two hundred cases of murder, suicide, and accidental death. In 1241 he went as a judge to Chhangchou [24] and there he had a chance to show what he could do in the field of literature, for he assisted Shih Nêng-Chih [25] in the compilation of a revised version of the local history and geography. ${ }^{13}$ In 1245 he became the Military Administrator and Prefect (Chih Chhangchou Chün Chou Shih [26]) of Chhangchou [24], but after two years he was summoned to Hunan to become the Judicial Intendant there (thi tien hsing yü [23]), and it was there that he completed his immortal book, the Hsi Yuan Chi Lu [1]. Finally, in 1249 he was called to be the Circuit Judge of all Kuangtung, and in that position he died at the relatively early age of sixty-four. ${ }^{14}$ Thus throughout his life he appears to have been an official of the highest quality, combining his compassion with a level-headed, indeed scientific (so far as the word could be applicable in his time), approach to the medico-legal problems in which he was particularly interested.

\section{THE 'HSI YUAN CHI LU'}

Let us now take a look at the Hsi Yuan Chi Luitself. Its importance was that it was the first systematic treatise on forensic medicine in any civilization. Sung Tzhu was driven to write it because in spite of all the work that had been done before his time, including the writing of collections of selected cases (to be discussed below), and the introduction of standard forms and pictures, there was still a great deal of dishonesty and inefficiency in inquest procedures. Sung Tzhu was deeply anxious to eliminate the resulting injustices.

We can read the preface which Sung Tzhu himself wrote in AD $1247 .{ }^{15}$ We have access to it now only through the Yuan edition of 1308, but fortunately that has been preserved. ${ }^{16}$ It gives a vivid account of the situation in his time. ${ }^{17}$

In judicial affairs, capital sentences are the most severe, in capital cases the most important things are the original circumstances and statements (chhu chhing [30]), and these fundamentally depend on the accuracy of the findings at the inquest. Hence will come the decision of the judge whether to grant life or to take it away. The judge and the prison officials (tso li [31]) must follow the law scrupulously as it is written down (thung chu [32]).

Recently in circuits and hsien cities the responsibility of conducting inquests has been delegated to young newly-appointed officials, and even to military officers, who have no suitable experience at all-yet they have to make the attempt. Moreover, the deceitfulness of ostensors (wu tso [ 7$]$ ) and the corruptibility of petty clerks (li hsü [33]), giving rise to all sorts of fantasies and falsifications, simply

\footnotetext{
13 This appeared in 1268 under the title Chhung Hsiu Phi-Ling Chih [27].

14 In 1957 his tomb was found in the hills near the village of Chhang-mou-tshun [28] in Chien-yang [29] county in Fukien. See Sung Ta-Jen (8).

${ }^{15} \mathrm{His}$ book was not an official government publication, and the edition was much smaller than the later official enlargements, of which the first appeared in 1662 (to be discussed below). The copy used by us was printed in Taipei in 1946, and the pages given are from this edition.

${ }^{16}$ In two versions. One was reprinted by Sung Hsing-Yen in 1867; it contains Yuan cases and regulations as an opening excursus. Another has been edited, with notes, by Yang Fêng-Khun (I) in 1980.

${ }^{17}$ Pp. 1-3, translated by the authors with the help of McKnight (1), pp. 37-8.
} 


\section{Lu Gwei-Djen and Joseph Needham}

cannot be over-estimated (lit., cannot be put into a submission on oath, kan chieh [34]). Even if a man be intelligent, he is, after all, limited, and lacks means to apply his wisdom. How much worse is the situation if he just looks on from afar, stopping up his nose, and taking no personal part in the investigation!

Four times I have been a judge, and although I have no other talents I felt it incumbent on me to be very careful indeed when deciding cases, never daring to be in the least dilatory or complacent. If cheating was obvious, then the prisoner's bluff had to be called; if the case remained obscure I was mainly afraid of taking action too quickly, for a dead person has no way of defending himself against injustice ( $h$ sü pei lao lu [35]). I often felt that wrong decisions in criminal cases derived from (errors in) the original statements, and from mistakes in the first inquest investigation; both of which stemmed from the trials and experiences of former times.

Therefore I collected the recent books on the subject, from the Nei Shu Lu [36] onwards, collating what they said, selecting the most important items, adding my own humble opinions, and I made the whole into a book, which I have called "Collected Writings on the Washing Away of Wrongs, or Unjust Imputations". The blocks for the printing were carved at the office of the Intendant of Hunan. I then showed the book to my colleagues, so that they could use it for reference and joint study.

It was quite like the physicians discussing ancient techniques. If you first clearly understood the circulatory system of pneuma (chhi [37]) and blood (hsüeh [38]), the mo lo [39], ${ }^{18}$ as well as the difference between the patefact and subdite signs (piao li $[40]$ ) - then you could never miss the right point for inserting the acupuncture needle. Thus the benefit of the "Washing Away of Wrongs" will have the same merit as that of saving the living from death.

And the Judicial Intendant of Hunan signed with all his official ranks and titles.

Sung Tzhu's emphases echo all the themes that run throughout the literature: the heavy load that rests on the conscience of the judge in seeing that true justice was done; the unreliability of the assistants and attendants, who were only too eager to accept bribes and to falsify the evidence; and finally the unreliability of the tests, assays, and verifications which had been accepted by the men of old. Later writers continually repeated this emphasis on the difficulties confronting the judges, difficulties which led to their efforts to alleviate the situation. It may not be without significance that Sung Tzhu ended his preface by an explicit comparison with what the physicians were trying to do; it was as if he felt the closeness of the connection between medical evidence and the criminal law, two systems not yet fully brought together but equally high-minded in their aims.

\section{FORENSIC MEDICINE IN CHINA BEFORE SUNG TZHU}

We have to study briefly the long history of forensic medicine in China before the time of Sung Tzhu. He himself mentions in his text three older legal writings which he found useful, though none of them look like the titles of books, nor are their authors known. They may have been simply essays by some of his predecessors. Apart from the Nei Shu Lu [36] already mentioned, one was entitled Shen Hsing Shuo [41] (Discussion on the Special Care Needed in Sentencing People to Punishments); another was entitled Wei Hsin Phien [42] (Examples of What Can Hardly be Believed); and the third was Chieh An Shih [43] (Form for Sentencing Criminals). All these may well have been written in the Northern Sung. ${ }^{19}$

One of the collections of cases before Sung Tzhu was the Chê Yü Kuei Chien [44] (Magic Mirror for Solving (Doubtful Criminal) Cases, or, Discerning False

${ }^{18}$ See on this Lu Gwei-Djen \& Needham (5), p. 25.

${ }^{19} \mathrm{Cf}$. Chung Hsü (I). None of these titles can be found in the bibliographies of the dynastic histories. 


\title{
A history of forensic medicine in China
}

Accusations). This was produced by Chêng Kho [45] in AD 1133, just after the fall of the Northern Sung to the Chin Tartars. ${ }^{20}$ Beyond that, the story went back to the Wu Tai period between Thang and Sung when Ho Ning [46] and his son Ho Mêng [47] published the I Y $\ddot{u}$ Chi [48] (Collection of Doubtful Criminal Cases, or, Redressing Wrongs Among the People). Sometimes these appear as I Yü Chhien Chi [49] by the father, and I Yü Hou $C h i[50]$ by the son. The former must have been written some time between AD 907 and 940 , the latter must have originated between 940 and 960 . But the books of the Ho family were by no means the first of this genre. In the Northern Chhi time (sixth century AD), Hsü Chih-Tshai [51] had produced a work entitled Ming Yuan Shih Lun [52](Discourse on Cases of the Bringing to Light of Unjust Imputations). ${ }^{21}$ Hsü's work has however not survived intact, though it might possibly be reconstructed from quotations.

As we have already intimated, the treatises which were distinctly medico-legal were preceded by others which might be called "case books". Thus in AD 1211 Kuei Wan-Jung [54] produced a remarkable work entitled Thang Yin Pi Shih [55] (Parallel Cases from under the Pear-Tree). This was a collection of comparable legal cases solved by eminent judges. ${ }^{22}$ It was printed in 1222 and again in 1234, so Sung Tzhu may have known it. Kuei Wan-Jung, who probably lived from about 1170 to 1260 , was actually a judge himself, but in 1208 he was nominated police inspector (ssu li tshan chün [56]) of the prefectural administration of Chien-khang, near modern Nanking. Kuei Wan-Jung was a successful administrator, a devoted Neo-Confucian philosopher, and a scholar particularly interested in medicine.

From his book we may take an outstanding example of the experimental approach to forensic medicine (though it is also related in the $I Y \ddot{u} C h i$, and Sung Tzhu must have known it). ${ }^{23}$ The account is as follows: ${ }^{24}$

\begin{abstract}
When Chang Chü [57] of the Wu dynasty (220 to $280 \mathrm{AD}$ ) was magistrate of Chü-chang, a woman murdered her husband and thereafter set fire to the house so that it burned down, falsely stating that her husband had burned to death. Her husband's family suspected her, and accused her before the authorities. The woman denied, and would not confess her crime. Chang Chü then took two pigs. One he had killed, the other he let live. Then he had both of them burned in a shed on a heap of faggots. On investigating (the difference between the two burned pigs, he found that) the pig previously killed had no ashes in its mouth, while the mouth of the pig burned alive was full of them. Then it was verified that there were no ashes in the dead man's mouth. When she was confronted with this evidence, the woman indeed confessed.
\end{abstract}

As van Gulik commented, it is quite interesting that Chang Chü chose pigs for his experiment, for it is well known that the anatomy and general size of a pig are very similar to those of the human body.

This is not the only time that the theme of experimentation occurs in the Thang Yin Pi Shih. For example we might quote the following. ${ }^{25}$

When the Academician-in-waiting (of the Thien-Chang pavilion), Hsü Yuan [59], at the beginning of his career (c. AD 1043) was Intendant of Exchange (in Chiang-Huai), he was greatly distressed by the fact that most of the official boats (proved unworthy; because the shipwrights) used less nails than

${ }^{20}$ It was re-issued in 1261 with a preface by Chao Shih-Tho [53]. See Sung Ta-Jen (9).

${ }^{21}$ See Chhen Pang-Hsien (I), p. 189.

${ }^{22}$ The author relied particularly on the $I Y \ddot{u} C h i$ and the Chê Yü Kuei Chien.

${ }^{23}$ Hsi Yuan Chi Lu, p. 75.

${ }^{24}$ Thang Yin Pi Shi, translated by van Gulik (6), pp. 102-3.

${ }^{25}$ Ibid., pp. 90-1. 


\section{Lu Gwei-Djen and Joseph Needham}

they charged for (since all the badly constructed boats had sunk, there was no means of checking the amount of nails actually used; thus the contractors could practise this deceit indefinitely). One day Hsü Yuan gave orders that a newly constructed boat should be burned. (After the ashes were raked through), the nails were weighed and found to represent only one-tenth of the amount actually paid for. Hsü Yuan then fixed the exact amount of iron nails to be used thence forward.

From this one can see that criminal trials and inquests were not the only problems facing the officials of the medieval Chinese bureaucracy.

\section{THE BAMBOO SLIPS OF CHHIN}

It should be emphasized that all the books before Sung Tzhu's Hsi Yuan Chi Lu were essentially collections of cases; it was he who had the originality and the organizing spirit to systematize the whole subject. Since his time all subsequent Chinese books on forensic medicine have taken it as their blueprint.

Recent archaeological research in China has succeeded in pushing back the concerns of forensic medicine, not only to the Han time but even to the Chhin. In 1975, several Chhin tombs were opened at Shui-hu-ti [59] near Yün-mêng [60] in Hupei, and in tomb No. 11 of this group, 1155 bamboo slips bearing records of legal cases were found. ${ }^{26}$ The man in question had almost certainly been a judge in the state of Chhin; he was born in 262 and died in 217 BC. The documents were written on ninety-eight bamboo strips, buried with the skeleton to the right of the skull, and in date they must run from 266 to about 246 BC. These twenty-five pro forma documents, entitled Fêng chen shih [61] (Models for Sealing and Investigating), must have been prized by the dead man so much that they were buried with him. We do not know his family name, but only his given name, which was Hsi [62].

Of the twenty-five specimen cases inscribed on the bamboo strips, four have special interest for our present theme. Let us give them, conflating the translations of Bodde, and McLeod and Yates. ${ }^{27}$

1. $5.19(\mathrm{E} 20)^{28}$

Death by robbery with violence (tsei ssu [63])

Report: A thief-catcher A belonging to guard-station X made an announcement, saying "At place $\mathrm{Y}$ within this jurisdiction there has been a death by murder. The victim was a single male person with bound-up hair (i.e. an adult), but his identity is not known. I have come to report."

We immediately ordered the prefectural clerk B to go and make an examination.

Report by the prefectural clerk B: "Together with prison-bondsman $\mathrm{C}$ we accompanied $\mathrm{A}$ to make the examination. The male corpse was lying in house $\mathrm{Z}$ straight out, facing upwards, and with its head to the south. On the left temple there was one knife wound, and on the back of the head some four inches long and one inch wide, with blood oozing from one to the other; the laceration was just like those made by an axe. The chest, temples, cheeks and eye-sockets of the corpse all exuded blood, which covered the body down to the ground, so that nowhere could the length or breadth of the bloodstains be established. Other than this, the corpse was intact.

"The clothes were of unlined cloth, skirt and jacket, one item each. The back of the jacket showed two vertical cuts, and was blood-stained, as also was the middle of the skirt. West of the body there was a pair of lacquered Chhin-patterned shoes, one of them a little more than six paces away from the corpse, the other ten paces. When the shoes were tried on its feet they fitted them.

${ }^{26}$ The publications and transcriptions into modern Chinese will be found in Anon. $(259,260,261)$.

${ }^{27}$ Bodde (28), McLeod \& Yates(1). Cf. Hulsewé (4), p. 193, and (6), pp. 183ff. All the present cases belong to Hulsewé's 'Group E'. It should be understood that all these papers are based upon a wealth of learned considerations, which we perforce omit here. For the original Chinese text in transcription, see Anon. (260), pp. $35 \mathrm{ff}$.

${ }^{28}$ The first numbers here are those of McLeod \& Yates, the second is Hulsewé's numbering. 


\section{A history of forensic medicine in China}

"The ground being very hard, we could see evidence of the assailant's footprints. The man had been able-bodied in the prime of life, light-complexioned, and seven feet two inches tall, with hair two feet long. On his abdomen there were two old moxibustion scars.

"From the place where the man's corpse was to A's guard-station X was some 100 paces, and to the farmhouse (thien shê [64]) of D, a member of the rank and file (i.e. a commoner) of E village was 200 paces."

We ordered A to cover the corpse with its cloth skirt, to bury it at place $F$ and to await further orders, after bringing the jacket and shoes to the Judicial Office (thing [65]). The people at A's guard-station, and those living near $\mathrm{C}$ are to be questioned to ascertain on what day (the man) died, and whether or not shouts of "bandit" (khou [66]) were then heard?

This wonderful document may be regarded as something from the very birth of orensic medicine; and for the third century BC the accuracy of description which was lemanded of the examiners is very striking. One would like to know more about what he thief got away with, and whether he was ever brought to justice; but one must emember that all these documents are essentially pro forma examples.

Let us now quote another of the bamboo slips.

\section{2. $5.20(\mathrm{E} 21)$}

\section{Death by Hanging (ching ssu [67])}

Report: A, the chief of X village, stated that "villager B, a commoner, has died by hanging in his home; the cause is unknown, and I have come to report".

We immediately ordered the prefectural clerk (ling shih [68]) $\mathrm{C}$ to go and make an examination.

Report of the prefectural clerk C: "Together with prison-bondsman D, I accompanied A, as well as B's wife and daughter, to examine the corpse of B. It was suspended from the cross-beam of the north wall within the eastern bedroom of the house facing south, by a hempen rope as thick as one's thumb. The noose was tied round the neck, and knotted at the nape; above it the rope was twice looped around the cross-beam and then tied in a knot, leaving a tail end some two feet long. The top of the head was two feet under the cross-beam, and the feet were suspended two inches above the floor. The head and back touched the wall, and the tongue protruded slightly; below, excreted faeces and urine had soiled both his legs. Upon releasing the rope, the breath issued with a gasp from the mouth and the nose. The rope left a compression bruise ${ }^{29}$ mark (around the neck) except for a two-inch space at the nape. Elsewhere the body showed no signs of knife-blade wounds or traces of (damage by) wooden (cudgel) or rope. The cross-beam was one span in circumference, three feet long, and projected westwards two feet beyond the edge of an earthen platform (on the ground below). From the top of this it was possible (for the deceased) to lead and bring together the rope around the beam. The ground being hard, no human footprints could be detected. The rope was ten feet long. The clothes consisted of an unlined jacket and skirt of unbleached silk, two items, and the feet were bare."

We immediately ordered A and the daughter of B to convey C's corpse and bring it to the Judicial Office.

When examining (a body) it is essential to make first a thorough and careful inspection of the evidence. Assuming he or she was alone at the place of death, one should note where the rope comes together (around the victim's neck) and see whether, at this meeting-point there are any traces of the rope's passage (around the neck). Check whether the tongue sticks out or not. How far away are head and feet, respectively, from where the rope joins (near the beam above) and from the floor (below). Have excrement and urine been voided? Then release the rope and see whether there is a gasp from the mouth and nose. Inspect the form of the bruises left by the noose, and try whether it can be released from the head. If it can, then remove the clothing, and examine the entire body from head to perineum. But if the tongue does not protrude, if the mouth and nose do not spurt air, if the imprint of the rope leaves no bruise, and if the knot of the rope is so tight that it cannot be loosened - then the true cause of death is difficult to determine. But if a long time has elapsed since the death, the mouth and nose will sometimes be unable to gasp.

When someone commits suicide, there must be a reason. Those who have lived together with the dead person should be questioned in order to elicit this.

${ }^{29}$ Cf. Gordon \& Shapiro (1), p. 96. 


\section{Lu Gwei-Djen and Joseph Needham}

Again we are amazed by the degree of precise detail and the quantitative exactitude with which the examiners scrutinised dead bodies in the third century BC. One notices the recognition of the possibility that the supposed suicide was really murder; and that the victim was strung up after death so as to simulate suicide, having first perhaps been poisoned. Although Sung Tzhu probably never saw these texts in the tomb of Judge Hsi, he was obviously the heir of a very long tradition.

Let us now examine another of the bamboo slips.

\section{3. $5.22(\mathrm{E} 23)$}

\section{A Miscarriage (chhu $t z u[69])$}

The denunciation of $\mathbf{C}$ by $\mathbf{A}$, both adult women commoners of $X$ village. It reads: " $A$ had been pregnant six months. But yesterday she had a fight with $\mathrm{C}$, who lived in the same ward; they seized each other by the hair, and $C$ knocked $A$ down, so that she fell against the screen inside the gate. Gentleman D, who also lived in the ward, came to the rescue and separated A and C. As soon as A got home, she felt ill with abdominal pains, and last night the child miscarried and was aborted. Now A, bearing the wrapped-up foetus, has come to denounce C."

We immediately ordered the prefectural clerk B to go and arrest C, then to examine the sex of the baby, how much hair had grown, and the appearance of the placenta. We also ordered a bondswoman (li chhieh [70]) E who has already borne several children to examine the appearance of A's emissions of blood from her vagina and her wounds. We also interrogated members of A's household about the condition in which she reached home, and the kind of pains which then came on.

Report by prefectural clerk B: "Bondswoman E and I have been ordered to examine A's foetus. At first, when wrapped in cloth, it was like a mass of (coagulated) blood, the size of a fist, and unidentifiable as a child. But then, when placed in a basin of water and shaken, the (coagulated mass of) blood was (seen to be) a foetus. Its head, body, arms, hands and fingers, legs down to the feet, and toes, were of human type; but eyes, ears, nose and sex were unidentifiable. When it was taken out of the water, it again had the appearance of clotted blood."

Another Report Form reads: "Bondswomen E and F, who have each had several children, were ordered to examine A. Both stated that there is dried blood beside her vagina, and that the bleeding is still continuing slightly, but it is not menstruation. E had a child, but it miscarried, and the bleeding then was just like A's now."

This passage shows how the medico-legal experts of the third century $\mathrm{BC}$ were trying to attain the same sort of accuracy as in the other cases, but could not do so owing to the lack of adequate embryological information. There is something garbled about what prefectural clerk B thought he saw, but no doubt he was doing his best. The immersion of the alleged foetus in water would not be a valid way of determining its characteristics. If it really was a foetus of six months, all its aspects would be clearly distinguishable without any immersion; nor would it again assume the appearance of a mass of clotted blood upon removal from the water. ${ }^{30}$

One possibility is that what the texts calls a foetus was actually a large clot of blood, the expulsion of which by the mother incidentally occurred with, but not as a result of, her fight with the other woman. But if this was so, prefectural clerk B could hardly have imagined the human characteristics of the foetus. One can only conclude that the

${ }^{30}$ One must remember, however, that the period of pregnancy was always counted as ten months in China, so the foetus may have been of five months only or less. This in fact was one of Dr Mennuti's suggestions. See note 31 below, and Sung Tzhu's description of human embryological development in $\mathrm{Hsi}$ Yuan Chi Lu, p. 44 . 


\section{A history of forensic medicine in China}

medico-legal experts in the third century $\mathrm{BC}$ were trying to do their best with this problem also, but in the absence of reliable embryological information could not get very far with it. ${ }^{31}$

Next we turn to the last of the cases we shall adduce from the bamboo slips of Judge $\mathrm{Hsi}^{32}$ It is different from all the others, because it deals with a particularly dangerous disease, against which the only defence, in ancient and medieval times, was the isolation of the patient from the rest of the population. ${ }^{33}$ Suffering from it, and yet going about at random, might be described as a quasi-crime, which is why it appears in this context.

4. $5.18(\mathrm{E} 19)$

$$
\text { Leprosy }(l i[71])^{34}
$$

Report: The headman $\mathbf{A}$ of $\mathrm{X}$ village has brought in villager $\mathbf{B}$, a rank-and-file commoner. His denunciation reads: "I suspect $l i$ (leprosy), and I have come along with him (to the Judicial Office)."

We interrogated B. His statement reads: "At the age of three, I suffered from sores on my head, and my eyebrows fell out; but the nature of the illness could not be determined. There is no other offence of which I am culpable."

Then we ordered the physician $\mathbf{C}$ to examine him. His statement says: "B has no eyebrows. The bridge of his nose is gone, his nostrils are rotted, and when I lanced what is left of his nose, he did not sneeze. His elbows and knees down to the soles of both feet are defective, and suppurating at one place. His hands have no hair (on the back). When I asked him to shout, his voice and breath were both feeble. It is leprosy."

This passage, which was also translated by Harper, shows how much concern the ancient Chinese had for public health. ${ }^{35}$ Moreover, it must have a great bearing on the origins of leprosy in the Old World. It cannot be shown to have existed in Biblical Palestine or ancient Egypt, and the earliest extant Western description of lowresistance leprosy is that of Celsus (25 BC-AD 37). He called the disease "elephantiasis", as did his contemporary Pliny the Elder (23-79 AD) who averred that it had only appeared in Italy about a hundred years before. The oldest Western clinical description is by Aretaeus of Cappadocia, about $150 \mathrm{AD}$.

In our discussion of records of diseases in ancient China, we pointed to a passage in the Analects $^{36}$ where Confucius is described as visiting a disciple afflicted with lai [72] or $l i$ and being willing only to touch the man's hand through the window. ${ }^{37}$ This was admittedly ambiguous, but we also found a page in the Huang Ti Nei Ching, Su Wên [73]

31 The discussion in Bodde (28), p. 9, is particularly illuminating here. He consulted Professor Michael Mennuti, a gynaecologist at the University of Pennsylvania.

32 Parallel entries for the first three of these cases are found in Sung Tzhu's $\mathrm{Hsi}$ Yuan $\mathrm{Chi} \mathrm{Lu}$, but he does not discuss leprosy, presumably because judicial courts in his time no longer considered cases of such diseases. Nor is it mentioned in the Hsi Yuan Lu.

${ }^{33}$ Elsewhere in the bamboo slips (D101, D102) leper colonies (leprosaria) are mentioned, and it is said that recalcitrant lepers not willing to live there must be executed by drowning: see Hulsewé (6), pp. 154-5.

${ }^{34}$ Equivalent to $l i[36]$ (as in Chuang Tzu, ch. 2, p. 21b) and lai. The discussions in McLeod \& Yates (1), pp. $152 \mathrm{ff}$., and Bodde (28), pp. $8 \mathrm{ff}$., are very instructive. It is noteworthy that in this case a medical man was consulted.

${ }^{35}$ Harper (3). The lepers were isolated from the general population in leprosaria (li so [75] or li chhien so [76]). See Bodde (28), p. 11. Sometimes it was directed that they should be executed, but this seems to have been the case only when they had committed some capital crime.

${ }^{36} \mathrm{Lu}$ Gwei-Djen \& Needham (4), pp. 12, 15: on Lun Yü, vi, 8, translated by Legge (2), p. 52.

${ }^{37}$ Actually the expression used was "evil disease", o chi [77], but nearly all the commentators identified it as leprosy. 


\section{Lu Gwei-Djen and Joseph Needham}

which made the identification much more tenable; ${ }^{38}$ it described the destruction of the "pillar of the nose" which is just as characteristic as the symptoms described in the bamboo slips, e.g. the loss of hair and eyebrows, the absorption of the nasal cartilage, difficult and hoarse respiration and, above all, peripheral anaesthesia. The first non-Chinese writer to mention the destruction of the nasal septum in leprosy was the Arabic philosopher and physician Ibn Sina (Avicenna, $d$. AD 1037), ${ }^{39}$ and the test for lepromatous anaesthesia was not recorded in the West until the time of Arnold of Villanova (d. AD 1312), so the general conclusion is that the disease was present in China at least by the third century $\mathrm{BC}$, a couple of hundred years before it was recognized and recorded in the Mediterranean region.

All this indicates a close connection with the doctrines of the Legalist School ( $\mathrm{a} a$ chia [78]). ${ }^{40}$ It can surely be no coincidence that we find the earliest evidences of forensic medicine coming from the State of Chhin, which had adopted their ideas. We contrasted the Legalist and Confucian (ju chia [79]) conceptions of law and justice at an earlier stage, and we must not go over all that ground again. ${ }^{41}$ Here it may suffice to say that the Legalists were fundamentally pessimistic, for they believed that the mass of the population pursued selfish ends, while the high-minded and altruistic were insignificantly few; therefore the law should be concerned mainly with the former. As always in China, the law was primarily criminal, not civil. Then the laws must apply uniformly to all, independent of birth, social position, rank or relationship. There can be only one single standard for morality, and it should be prescribed by law; the law-givers might ponder and argue about it beforehand, but once promulgated, the law must be followed by everyone. If the laws are sufficiently stringent (or, as some would say, draconic) they will never have to be applied, since their very existence, provided everyone knows about it, will be enough to deter wrong-doing. In this day and age, we may well have doubts about any theory of deterrence, and indeed it did not stop the acts which led to the cases on the bamboo slips of Judge Hsi.

However there was something proto-scientific about Legalism, some soil out of which medico-legal investigations could grow. The laws, said the Legalist philosophers, should be clearly written down, exactly stated, and not subject to individual interpretation. They should have something about them like the indifference of Nature, like "the rain that falls both on the just and on the unjust". Hence the scientific objectivity, one could almost say, with which human actions must be probed, elucidated, judged, and if necessary, punished; and since human nature may, in certain circumstances, be very deceitful, the coroner (to give him his medieval English name) must use to the maximum the knowledge of the medical science of his day, in order to establish what exactly had happened. There was also a fascination with the quantitative and its measurement, which comes out again and again in Legalist writing. These perhaps were the aspects of Legalism that favoured the

${ }^{38}$ Huang Ti Nei Ching, Su Wên, (I Thung Chêng Mo Chhüan Shu edition), ch. 12, p. 2a.

${ }^{39}$ For a famous case in eleventh-century AD China, see H. Wilhelm (17), p. 280. Liu Pin [80], a friend of the poet Su Shih [81], died of it in 1088 .

40 These we discussed at some length in SCC, vol. 2, pp. $204 \mathrm{ff}$.

${ }^{41}$ Ibid., pp. 3ff. 


\section{A history of forensic medicine in China}

appearance and growth of forensic medicine. If in the end history gave the victory to the Confucians, it was because they allowed for a certain humanistic element in ideal justice, recognizing human beings to be no robots but the most highly organized and complex organisms known, the springs of whose actions are very deep and subtle. Yet the application of science and medicine to law may well turn out to have been a characteristic contribution of Legalism.

\section{EARLIER EVIDENCE}

Beyond this point, as we press back our investigation of forensic medicine into the mists of antiquity, there is not much to be found; though the very advanced state of the legal formulations of Chhin argues a long antecedent development. Of law and legal actions there is quite a lot to be said, but of medico-legal expertise not so much. For example, one may have a look at the Yüeh Ling [82] (Monthly Ordinances of the Chou Dynasty), a work which must date from the third century BC, but parts of which may go back as far as the seventh century BC. ${ }^{42}$ In 239 BC it was incorporated whole into the $L \ddot{u}$ Shih Chhun Chhiu [83] (Master Lü's Spring and Autumn Annals; a Compendium of Natural Philosophy). A couple of centuries later it was also incorporated in the $\mathrm{LiChi}$ [84] (Record of Rites), compiled by Tai the Younger [85], whence it was translated by Legge. ${ }^{43}$ One finds the following entry for the first month of autumn (mêng chhiu chih yüeh [86]): ${ }^{44}$

\footnotetext{
In this month orders are given to the proper officers to revise the laws and ordinances, to put the prisons in good repair, to provide handcuffs and fetters, to repress and stop villainy, to maintain a watch against crime and wickedness, and to do their best endeavour to capture criminals.

Orders are (also) given to the judicial officials-in-charge to investigate superficial bruises (shang [87]), to examine open (or bleeding) wounds (chhuang [88]), to look for damaged bones and sinews (chê [89]), as well as those which are broken (tuan [90]). ${ }^{45}$

In judging cases, it is essential for officials to be correct and fair; those who have committed the crime of killing others must receive the most severe punishment.
}

This still remains the oldest statement of forensic medicine in Chinese literature. ${ }^{46}$

Here one remembers that all through Chinese history criminals were executed only in the autumn, so as to be in harmony with falling leaves and falling snow. Thus for the second month of autumn the text goes on to say:47

Orders are given to the proper officers to revise with strict accuracy (the laws about) the various punishments. Beheading and (the other) capital executions must be according to (the crimes committed) without excess or defect. Excess or defect out of such proportions will bring on itself the judgment (of Heaven).

${ }^{42}$ On the date of the Yüeh Ling see SCC, vol. 3, Mathematics and the Sciences of the heavens and the earth, p. 195.

${ }^{43}$ Cf. Legge (7), p. 259.

${ }^{44}$ Legge (7), p. 285.

${ }^{45}$ Li Chi, ch. 6 ( Yüeh Ling), pp. 72b, 73a. Legge (7) seems to have understood this passage to refer mainly to the governors of prisons, but we follow Tshai Yung's [91] commentary, which makes it clear that the words refer also to judges in charge of inquests. Most commentators agree: see Yü Chu Pao Tien [92] (Sui Shih Hsi Su Tzu Liao edition), ch. 7, p. 6 (p. 424). Cf. Chuko Chi (I).

${ }^{46}$ It may not be without interest that Chang Fu [93], the brother-in-law of Kuei Wan-Jung, compiler of the legal case-book Thang Yin Pi Shih, also wrote a commentary on the Yüeh Ling entitled Yüeh Ling Chieh [94]. Cf. van Gulik (6), p. 7.

${ }^{47}$ P. 75 a, b, translated Legge (7), p. 288. 


\section{Lu Gwei-Djen and Joseph Needham}

Finally, for the last month of autumn: ${ }^{48}$

In accordance with (the season) they hurry on the decision and punishment of criminal cases, not wishing to leave them any longer undealt with.

Thus one can say from such a text that a legal system was in force and that there were punishments for evil-doers, but we are not told very much about the medico-legal aspects of the magistrates' activities. Of course records of legal cases as such go back far into the beginning of the first millennium BC in China. For example, in 1975 an excavation at Chhi-shan [95] unearthed from a tomb dating from about $820 \mathrm{BC}$, a bronze ladle with a handle ( $i[96])$, bearing an inscription (Chen i ming wên [97]) giving a record of a court case. ${ }^{49}$ It relates many such details as the basis on which sentence was given, the process of reduction of a sentence, and how the guilt was eventually dealt with. The case was heard by a famous judge, Pai Yang Fu [98]. It recorded the summing up of a trial in which an individual named $\mathrm{Mu}$ Niu [99] filed a suit against his official superior (shang ssu [100]) Chen [101], but Mu Niu lost and was sentenced to be branded or tattooed (chhing hsing [102]), after which he was pardoned and did not even have to pay a fine (wei fa chin [103]). But then later on he brought another suit which again he lost, and this second time he was sentenced to a thousand strokes of the whip (pien [104]). This was after a while reduced to five hundred, and eventually commuted to a fine, so that he had to pay 300 huan [105] (an ancient weight) of bronze to Chen, after which the metal was used to make the ladle with its inscription.

Sometimes these fines were paid in armour. It seems that $\mathrm{Mu}$ Niu was some kind of dependant of Chen, so that in bringing the suit he had to break his oath of allegiance. After the first trial, he took it again, and after the second trial he renewed it once more, but with the words dictated by Pai Yang Fu added "I will not dare henceforward to disturb your affairs." Unfortunately, the inscription does not say what the suits were about, so we do not know whether there was any criminal aspect in the matter.

Another case comes from the very early Chou time (tenth century $\mathrm{BC}$ ) ${ }^{50}$ The record is inscribed on a ting [106] or bronze cauldron with three legs, and takes the form of the declaration of a judgment. A military officer with the personal name of Chhi [107] alleged that his inferiors, the defendants, had not followed him to fight for the High King of Chou. The judge, Pai Mou Fu [108], eventually fined the chief defendant 300 huan of bronze (a weight equivalent to about 2000 Han ounces liang [109], or 125 catties, chin [110], but the defendants would not pay. Eventually Pai Mou Fu ordered them to be banished, but rather than that they decided to pay the fine, and it was out of this bronze that the ting was made.

This is about as far back then as we can trace the beginnings of legal and judicial proceedings. Once again, as in the case of the Yüeh Ling, there is relatively little about legal medicine, so it does seem that this first began to arise in the State of Chhin in the Warring States period-and perhaps with the Legalist School.

\footnotetext{
48 P. 81, translated Legge (7), p. 295.

${ }^{49}$ See Shêng Chang (l), p. 42; and Phang Pho (l).

50 See Thang Lan (5), p. 33.
} 
THE DEVELOPMENT OF THE SUBJECT IN YUAN AND MING

Before going further with Sung Tzhu's original text, one has to understand that because of the special circumstances it became the basis for many subsequent editions, being greatly enlarged in the process, particularly after the appearance of the government-commissioned work of AD 1662, described below. This has meant that some discoveries and techniques have been attributed to Sung Tzhu which were not really his, but of a later date ${ }^{51}$ and this has happened not only in the European, but also in the Chinese, secondary literature, ${ }^{52}$ including recent biographies. Sung Tzhu's book originally had five chapters. The first one had four sections, the second had twelve, the third had five, the fourth had ten, and the fifth had twenty-two; the sections alone had titles. 53

We must now have a look at the books which followed upon Sung Tzhu's Hsi Yuan $\mathrm{Chi} \mathrm{Lu}$. The subject must have been very much "in the air" because another writer, probably Chao I-Chai [111], wrote a work called Phing Yuan Lu [112] (Pacification by the Redressing of Wrongs), probably about AD 1255. Since the work has not survived, and since there is an element of uncertainty about the ascription, we cannot tell the exact date, but it was certainly later than Sung Tzhu's. After the Yuan dynasty had taken over, Wang Yü [113] in AD 1308 wrote a two-chapter work entitled Wu Yuan Lu [114] (The Cancelling of Wrongs, i.e. False Charges). ${ }^{54}$ This became the basis of forensic medicine in Korea and Japan, ${ }^{55}$ but in China preference was always given to the work of Sung Tzhu. The three books were sometimes collectively printed as the Sung Yuan Chien Yen San Lu [115] (Three Treatises on Inquest Procedure from the Sung and Yuan Periods), but Sung Tzhu's work always remained the most widely consulted.

A few more details about the transmission to Korea and Japan might be in order here; the later European translations will be described below. The $W u$ Yuan Lu was printed as such in Korea in AD 1384, but in 1438 the Hsin Chu Wu Yuan Lu [116] was finished, forming the fundamental text on the subject for long afterwards. It had a preface of 1447 by Liu I-Sun [117], who may well have been its editor. The textbook was then certainly transmitted from Korea to Japan, some say by the close of the sixteenth century, and the standard work there, prefaced in 1736 by Kawai Jinhyōe [118], appeared as the $W u$ Yuan $L u S h u$ [119] in 1768. It would be interesting to study these developments more closely, but this may be sufficient in the present context. It shows the expansion of Sung Tzhu's work in surrounding countries.

Indeed it went through many editions during the centuries which followed him. Under the Yuan, the work remained in five chapters; this was the recension which

\footnotetext{
51 This shows that the subject was developing strongly in these subsequent centuries.

52 As has been shown in detail by Juan Chhêng-Hsüeh (I). For example, arsenic and carbon monoxide poisoning, etc.

${ }_{53}$ See the contents table in McKnight (1).

54 The book was based on both the preceding ones, with some modifications and additions; it distinguished more carefully than ever between suicide by hanging and murder by strangling. It also corrected the age-old error about the relative positions of the trachea and oesophagus, maintaining the former is anterior to the latter. Cf. Chung Hsü (I).

55 The story has been told in detail by Chia Ching-Thao (2) and Sung Ta-Jen (9).
} 
Sun Hsing-Yen [120] republished in 1808, and the version translated by McKnight. But there were many other editions in the Ming, for example, Chang Ching's [121] Pu I Yü Chi [122] (Additions to the 'Collection of Doubtful Criminal Cases'). The work, now in one chapter, was appended to two of the legal publications deriving from the Ming code, Ta Ming Lü Hsing Shu Chü Hui [123] and Ta Ming Lü Li Chih Chün Chhi Shu [124].

\section{THE DEVELOPMENT OF THE SUBJECT IN CHHING TIMES}

During the course of the Chhing dynasty, at least ten editions appeared. One of the first, certainly the most important, was the Lü Li Kuan Chiao Chêng Hsi Yuan Lu [125] (Book of the Washing away of Wrongs, collated and verified by the Office of Laws and Regulations), published in AD 1662 and again in $1694 .{ }^{56}$ More than a dozen old medical books were laid under contribution for this work, which was carried out by a committee commissioned by the Khang-Hsi emperor; ${ }^{57}$ the sub-headings were rearranged, the contents much enlarged, and the number of chapters reduced to four. All the subsequent treatises used this as their basis. A hundred years later, in 1770, came the Chien Ku Thu Ko [126] (Standard Form of Chart for the Notation of Injuries to Bones), under the Chhien-Lung emperor, one of the earliest examples of a form to be filled in from any civilization, as we shall see. This was at once ordered to be included in the former work. Then the traditional coroner's manual took approximately its existing form, in the Hsi Yuan Lu Chi Chêng [127] (The Washing Away of Wrongs, Collected and Checked), organized in 1796 by Wang Yu-Huai [128]. Later editions have a commentary of 1832 by Juan Chhi-Hsin [129], ${ }^{58}$ another of 1837 by Chang Hsi-Fan [130], ${ }^{59}$ and a preface by a salt official, Thung Lien [131], dated 1843. This shows that Giles's translation must have been done from one of these books. ${ }^{60}$ Another, later version was prefaced in 1852 with the title Hsi Yuan Lu Hsiang I [132]; this was the edition of Hsü Lien [133]. ${ }^{61}$ The full bibliographical details were given by Pelliot ${ }^{62}$ with his customary exhaustiveness, but one derivative work he omitted, namely the $\mathrm{Hsi}$ Yuan Lu Chien Shih [138] (A Commentary on the 'Washing Away of Unjust Imputations, or Wrongs'), written by the eminent physician Wang Khên-Thang [139] near the end of the Ming, $c$. AD 1602. This has become very rare, but its publication was an event of some importance in view of the parallel intervention of the medical profession at this time in the Western world.

There is another indication of this world-wide change, too. We are fortunate enough to have a copy of the first chapter of the Hsi Yuan Lu Pien Cheng [140] (Correction of

\footnotetext{
${ }^{56}$ Neither of these editions had any preface or postface, nor were any references given: see Sung Ta-Jen (9).

${ }^{57}$ The custom of leaving out the 'Chi' from the titles of works derivative from the Hsi Yuan Chi $\mathrm{Lu}$ probably dates from this time.

${ }^{58}$ The book was then entitled Pu Chu Hsi Yuan Lu Chi Chêng [134].

${ }^{59}$ The book was then called Chhung Khan Pu Chu Hsi Yuan Lu Chi Chêng [135]. It has five pên with four chapters, because it has some other tractates, printed at the back.

${ }^{60} \mathrm{Giles}(7)$. We say this, because each provincial jurisdiction printed its own copy. One of our own editions is from Yunnan, and has four pên with four chapters.

${ }^{61}$ The importance of this work (published 1854) was that it marked a definite step forward in Chinese osteology ( $k u$ ko hsüeh [136]). Hsü Lien had been a judge for twenty years, and whenever he attended a suitable inquest he took along a professional artist (hua chiang [1337]) to draw the skeleton. See Chung Hsü (I), p. 501.

62 Pelliot (13), p. 126.
} 
Mistakes in the (Government Editions) of the 'Washing Away of Wrongs'), written by an excellent scholar named Chhü Chung-Jung [141] in 1827. It is contained in the fifth pên of a Chung Khan Pu Chu Hsi Yuan Lu Chi Chêng edition of 1847, together with other treatises. It was he who identified the medical and other books which the Lü Li Kuan committee had used in the seventeenth century; they included some twenty titles such as Huang Ti Nei Ching, Su Wên, Chhi Hsiao Liang Fang, Ming I (Pieh) La, and Chhao Shih Ping Yuan. ${ }^{63}$ Together with the newly discovered Yuan edition of the original book, this is one of the most important findings to help us distinguish between Sung Tzhu's own text and the ideas which were imported into it at later dates, especially in the government editions. Recently Kuan Chhêng-Hsüeh listed many such errors: certain poison antidotes, and the occurrence of carbon monoxide poisoning, were not in the original text, for example; using eggs and emetics to cure arsenic poisoning is also a later notion. ${ }^{64} \mathrm{Such}$ mistakes, which have got into recent Chinese medical textbooks and encyclopaedias, are really rather serious - the moral is that, wherever possible, original texts should be consulted. This is why it was quite acute of Sydney Smith to say: "It would be of great interest if some student of Chinese history could unearth and translate an undoubted mediaeval text of the Hsi Yuan Lu."65 But he also wrote "I am left with the conviction that in mediaeval times Chinese forensic medicine was far in advance of contemporary European practice". 66

After Hsü Lien's time, books continued to be written on the subjects discussed in the Hsi Yuan Lu, but they were of little importance. European anatomy and forensic medicine now came in gradually more and more, thus leading to the synthesis of the present day. ${ }^{67}$

In the late edition (1843) that Giles used for his translation, the Hsi Yuan Lu consists of four chapters, ${ }^{68}$ each with several sections: the first has sixteen; the second, twelve; the third, six; and the fourth, three. Subjects dealt with in the first group

${ }^{63}$ See pên 5 , ch. 6A, p. 3a; and particularly Sung Ta-Jen (9), p. 281 on this subject.

${ }^{64}$ Kuan Chhêng-Hsüeh (l).

${ }^{65}$ Smith (1), p. 602 . Echoed by Gradwohl (1), first ed., p. 7.

${ }^{66}$ Also echoed by Gradwohl (1), ibid.: "It was very far ahead of anything which existed anywhere else in the world when it was first written."

${ }^{67}$ For an account of this development see Chung Hsü (I) and the book of Kuo Ching-Yuan (I). It can be followed further in Chhen Khang-I ( $I$ ) and Chin Ching-Thao ( $I$ ).

${ }^{68}$ Giles (7). Giles called his chapter "books", and his sections "chapters". This translation, until recently, was the best known, although now McKnight (1) has given us a translation of the Yuan edition which brings us as near as we can get to Sung Tzhu himself. The first appearance of his book in a Western language was a abbreviated text by the Jesuit Cibot (8) in 1779. Another, rather fuller, French version by Martin (1) saw the light more than a century later, in 1886; while Litolf (1) did a translation into French from the Vietnamese, which appeared in eight issues of a Hanoi journal in 1909 and 1910. The first complete translation into a Western language was into Dutch, by de Grijs (1) in 1863; and this was in turn rendered into German by Breitenstein (1) in 1908. It was done from the edition prepared by Wang Yu-Huai [128]. Another German translation, by one Hoffman, is mentioned by Shangkuan Liang-Fu (1), but a search in Western library catalogues, including that of the British Library, has failed to confirm or identify it. Perhaps the most likely person would be the Japanologist John Joseph Hoffman, who was active between 1834 and 1877. Similarly there is said to be a Russian translation, but we have not been able to establish any details about it: see Anon. (202), p. 479; Yang Wên-Ju \& Li Pao-Hua (1), p. 121; and Shih Jo-Lin (1), p. 37. We know now that not one of these translations, except that of McKnight (1), represented the text of the Hsi Yuan Chi Lu itself. 


\section{Lu Gwei-Djen and Joseph Needham}

comprise real and counterfeit wounds, the examination of decomposed corpses, the examination of bones whether injured before or after death, and notes on decomposition of the body at different seasons. The second group deals with wounds, whether inflicted by the hand or foot, or with weapons generally; suicide with weapons; suicide by strangulation; and burning, whether before or after death. The third group discusses miscellaneous suspicious appearances, and the results of falling from a height or being crushed to death; it also takes up many kinds of poisons and their effects. Finally, the fourth group considers methods of restoring life, e.g. after hanging, drowning, scalding or freezing; and it continues the pharmacological notes on poisons.

Next, one cannot do better than quote a piece from the opening chapter of the Chhung Khan Pu Chu Hsi Yuan Lu Chi Chêng. ${ }^{69}$

There is nothing more important than human life; there is no punishment greater than death. A murderer must give life for life, the law shows no mercy; but to obviate any regrets which might be occasioned by a wrong infliction of such punishment, the validity of a confession and the sentence passed depend on a satisfactory examination of the wounds. If these are of a bona fide nature, and the confession of the accused tallies therewith, then life may be given for life, that those who know the laws may fear them, that crimes may become less frequent among the people, and due weight attached to the sanctity of human existence. If an inquest is not properly conducted, the wrong of the murdered man is not redressed, new wrongs are raised up against the living, other lives sacrificed, and both sides aroused to vengeance of which no man can foresee the end.

In important cases where death has not already ensued, everything will depend on the energy of the judge or official-in-charge in proceeding instantly to a personal examination of the victim - noting down the wounds, their position and severity-and fixing the "death-limit" in the hope that medical skill may effect a cure; so that in case of re-examination after death with a view to obtain a different verdict, the unpleasantness of dissection may be avoided.

Where death has already resulted from the wounds, there is still greater need for promptitude ere decomposition sets in, and while as yet it is easy to note the severity and size of each wound. For while you are delaying, the body is beginning to decompose. To guard against the infliction of false, or the tampering with real, wounds is a principle of the highest importance. No, the judge and his assistants (particularly the ostensor, see below) should hasten to the spot with all speed, so that the guilty parties may have no time to concoct schemes for evading the consequences of their crime.

If death has just taken place, first examine the top of the head and the back, the ears, the nostrils, the throat, the anus and the vagina, in fact all places where anything might be inserted, on the chance of finding a sharp-pointed instrument of some kind or other. If nothing is found, proceed to examine the body in the regular way.

If it should be a case where examination of the body is necessary, first carefully interrogate the relatives of the deceased, the neighbours, and the accused, bidding them state clearly who struck whom with what weapon, and in what part of the body; the deposition of each being taken down in writing.

Then with your assistants, the petitioner, and the accused, proceed to the spot where the body lies, and examine it as the law directs. Mark what wounds are on vital spots, ${ }^{70}$ whether on the trunk or extremities, whether skin or flesh wounds, whether penetrating to the bone, their colour, exact size and shape (blue, red, purple or black); whether inflicted by the hand or foot, or by some weapon, circling them with a line; their severity and appearance, whether recent or old. All this must be carefully elucidated, and the prescribed form filled up with your own hand, not by the assistants. Do not, deterred by the smell of the corpse, sit at a distance, your view intercepted by the smoke of fumigation, letting the ostensor call out the wounds and enter them on the form, perhaps garbling what is of importance, and giving prominence to what is not, adding or subtracting as he sees fit.

${ }^{69}$ Translated by Giles (7), p. 61, from the Chhing government edition of 1843 , modified by the authors.

${ }^{70}$ On this see Lu Gwei-Djen \& Needham (5), pp. $302 \mathrm{ff}$. 
Moreover, death from self-strangulation, throat-cutting, taking poison, burning, drowning and the like, produce very different results, and only the most minute investigation of every little detail will ensure a complete and reliable verdict. If this be neglected, the ostensor and the secretary will intrigue and make light of the whole affair; the culprit will devise some means for escaping punishment, the relatives of the deceased will appeal against your decision, mischiefmakers and bad characters will seize the opportunity, and the end of it all will be that your verdict will be discredited, another trial judge deputed, and the steaming of the corpse to obtain the skeleton will become a matter of necessity, an outrage on the dead and an inconvenience to the living. These are the evils attendant on a dilatory or perfunctory discharge of your duties.

There are several things here which could do with some explanation. For example, the idea of the "death-limit" (pao ku [142], or shou ku [143]) was something which so far as we know did not occur in Western medieval law. It might be better translated, perhaps, as "period of responsibility" or "liability time-limit", and it was widely recognized in Chinese legal procedure. The wounded person was handed over to the care of the family of his or her assailant for a precisely specified period, ${ }^{71}$ the idea being that the latter would be so anxious to avoid the penalty for murder that he would get the best medical advice that money could buy and nurse the person back to health. ${ }^{72}$ If a cure was not effected within the limit of time laid down, the assailant was considered guilty of the damage, and vice versa; if death occurred, even only half a day after the time limit had expired, the assailant was not held responsible. This system protected both the victim and the assailant.

Secondly, the filling-in of forms by the judge during an inquest has an extraordinarily modern ring about it, but in fact the forms had been introduced somewhat earlier in the Sung period by Chêng Hsing-I [145], whose writing was entitled Chien Yen Ko Mu [146] (Inquest Forms to be Filled in during the Examination of the Corpse) ${ }^{73}$ This dated from AD 1174. As Li Hsin-Chhuan tells us, Chêng was a circuit judge or judicial intendant (Chê Hsi Thi Tien Hsing Yü [147]) and was struck by the muddle, dishonesty and injustice at inquests during his time. So he devised a special form with a serial number, on which many aspects of the case had to be filled in, notably the name of the injured person and of his or her attacker, the date and time of the offence, the distance of the place from the judge's office, the number of wounds and the cause of death, together with the names of the officials concerned. ${ }^{74}$

\footnotetext{
${ }^{71}$ For example, when the extremities were wounded by an instrument, the period was twenty days. For a knife wound, boiling water or fire, the limit was thirty days. For other wounds the time was ten days. When bones were broken or when miscarriage was brought on, the period was fifty days. Such were the prescriptions laid down in the Tou Ou Lü[144](Regulations of Fighting). See Chhung Khan Pu Chu Hsi Yuan Lu Chi Chêng; ch. 1, p. 10a.

${ }^{72}$ For further details, see van Gulik (6), p. 92 and Alabaster (1), pp. 229ff. The practice must have been a very old one, for it is mentioned in the first century BC dictionary Chi Chiu Phien [148], written by Shih Yu [149], (p. 67a).

73 Not only were these forms drawn up in such a way as to give clear information, but since Hsü Ssu-Tao's [150] time (AD 1211) they also included two outline sketches of the form of the human body (front and back), so that the position of the wounds could be marked on it. Coloured inks were used. Thus the information called out by the ostensor could be seen by all present to correspond with the truth. The pictures were adopted by the highest judicial authorities and were known as Hunan Thi Hsing Ssu Ko Shih [151], (Pictures developed by the Judicial Intendant of Hunan).

${ }^{74}$ Chien-Yen I Lai Chhao Yeh Tsa Chi [152](Miscellaneous Records of Court Officials and Common People since the Chien-Yen Reign-Period [AD 1127-1130]), pt. 2, ch. 11, p. 474a, b, in the Tshung Shu Chi Chhêng edition. A similar account comes in the Sung Hui Yao Kao [153]; it adds details of a second request when this was necessary (Tshê $170 \mathrm{Hsing}$ Fa, pp. 5a, b, 6a, b).
} 


\section{Lu Gwei-Djen and Joseph Needham}

Then, in 1204, some judge in Hunan and Kuangsi introduced anterior and posterior outline diagrams of the human body, so that the coroner in inquests could make the place of the wounds or contusions (Chien Yen Cheng Pei Jen Hsing Thu $[154])^{75}$

The preparation of forms to be filled in was an idea which arose naturally out of the passion for justice and the bureaucractic character of Chinese society. They had to be completed in triplicate, one to go to the office of the Prefect (chih chou [155]), one to be given to the victim's relatives (chhin tsu [156]), and one to be kept by the judge or official-in-charge (thi hsing [157]). We are accustomed to think of the filling-in of forms as something very recent in Western Europe ${ }^{76}$ and so no doubt it is, but some of the sea-captains who visited the coast of China in the eighteenth century and needed repairs to their ships, were extremely surprised to find that the magistrates along the coast had forms to be filled in - how much wood required, how many carpenters, and so on. ${ }^{77}$ It is just another indication that the bureacratic system of Chinese government was far ahead of Europe for many centuries.

Lastly there is the question of the ostensor (wu tso [7]). A rather lowly official, he drew attention to the wounds on the body and called out their nature to the judge; he also did all the preparation of the body for examination and any simple experiments that were required. ${ }^{78}$ Much emphasis was placed on the washing of the body with vinegar-no doubt an antiseptic procedure. Late fifteenth-century pictures of anatomical dissections in Europe show the professor in his robes seated up aloft in a stall and reading from the book. Down below, a menial demonstrator or prosector actually did the dissection, while an ostensor demonstrated with a wand the various parts to the students, who did not do any dissection themselves. ${ }^{79}$ This word, then, meaning "he who shows", is therefore quite a good choice for describing the functions of the wu tso $[7] .^{80}$

The history of the wu tso (ostensor) and his functions has been written by Chia Ching-Thao and Chung Hsü. ${ }^{81}$ They tell us much about the titles of the judge, who in

\footnotetext{
${ }^{75}$ Both of these were included in the Yuan edition of the Hsi Yuan Chi Lu (pp. 10, 11).

${ }^{76}$ See Gradwohl (1), third ed., pp. 60, 76, 101-3. The practice may go back to the standardization of medical reports in the books of de Blégny (1684) and Devaux (1693), cf. ibid., p. 9. On Ambroise Paré (1575) and reports see below.

${ }^{77}$ Here the key passage occurs in the account of Admiral Anson's voyage around the world between 1740 and 1744: Walters (1), entry for 19 December 1742. A "mandarine", deputed by the Viceroy of Canton, visited Anson's ship the Centurion in Macao roads, and took down all the particulars about the necessary repairs on previously-prepared forms, so that the ship stood to sea again on 19 April of that year. For knowledge of this we are indebted to Mr G. F. Peaker and Dr Ulick R. Evans. Perhaps the origins of the form for filling in should be sought in those lists of goods and possessions so common in Babylonia and ancient Greece. Certainly by the Han time, the military records of Chü-Yen seem to include many indent forms needing to be filled in: cf. Loewe (4).

${ }^{78} \mathrm{Cf}$. van Gulik (6), p. 60. The term was certainly used in Sung Tzhu's time: cf. Hsi Yuan Chi Lu, Ling Nan edition, pp. 40-1.

${ }^{79}$ See for instance the illustration from the Italian Fasciculo di medicina printed at Venice in 1493, which forms the first page of an Italian translation of the Anothomia (1316) of Mondino de Luzzi (c. 1270-1326). It is reproduced by Singer (25), fig. 35, p. 7.

${ }_{80}$ Originally he was an undertaker or a butcher, underpaid, socially despised, and often ignorant. Children of such families were not admitted to the imperial examinations. See Chia Ching-Thao (I); Yao Tê-Yü (I). The latter quotes the saying, "Never base your report only on what the ostensor says."

${ }^{81}$ See Chia Ching-Thao (1) and Chung Hsü (2).
} 


\section{A history of forensic medicine in China}

ancient times was ling shih [68], then in the Thang hsien wei [158]; in Sung Tzhu's time he was thi hsing [157], and after the coming of the Yuan dynasty, he became chêng ming ssu li [159]. About the ostensor (wu tso), Ho Mêng [47] had a good deal to say in his Yü Thang Hsien Hua [160] (Leisurely Talks in the Academy), ${ }^{82}$ written in the Wu Tai period, about 950 AD. The term also appears in the Chê Yü Kuei Chien [44] (Magic Mirror for Solving Doubtful Criminal Cases) written by Chêng Kho [45] in AD 1133 and reprinted in 1261. An early name for the ostensor was hsing jen [161] or "runner", because he made haste to get to the place where the dead body was found ${ }^{83}$ When not on duty, he might well be an undertaker, or at least a seller of coffins. A few years after the Yuan dynasty came in, from 1268 onwards, the new laws gave the wu tso more responsibility, because while the judge still had to participate in the examination of the body himself, the wu tso had to sign a paper guaranteeing that the facts established were true. In cases of poisoning medical men were now called in. During the early Middle Ages, the wu tso were at first a rather depressed group, but before the end of the Chhing dynasty, special training schools were made for them, and eventually they got the title of Inspector (chien yen li [162] or chien yen kuan [163]), and were placed in the ninth rank of the bureaucracy.

\section{MATTERS OF MEDICAL INTEREST}

As we have seen, Sung Tzhu's Hsi Yuan Chi Lu of AD 1247 was the consolidation of all previous knowledge in forensic medicine; it contains five chapters. Subsequently his work was rearranged in various way by different authors using different titles, but a great enlargement came in 1662 with the Lü Li Kuan Chiao Chêng Hsi Yuan Lu, when the work was divided into four chapters. Much new medical material went into this. We shall thus distinguish, in what follows, between the Hsi Yuan Lu and the Hsi Yuan Chi Lu.

Now when we come to the specifically medical content of these treatises, there is much of great interest. As Smith has said, one certainly gets the impression that there was a comprehensiveness in the scope of medico-legal procedure in medieval China that was not to be found in medieval Europe. ${ }^{84}$ Throughout there runs a strong insistence on the examination of the body itself; the wounds which it carries are to be noted down so that the validity of confessions or other statements may be checked. ${ }^{85}$

The "vital spots" or sites where any trauma, contusion, or shock will be exceptionally perilous, leading to internal injury or death, sometimes even with no external sign of wounding at all, are carefully listed. ${ }^{86}$ They were given names like those of acu-points. These points of particular danger, on which a person's fate might depend (chih ming chih $c h h u[164])^{87}$ were enumerated as sixteen on the front of the body (or twenty-two if all the bilateral points were counted) and six on the back (or ten if all the bilaterals count),

\footnotetext{
${ }^{82}$ See van Gulik (6), pp. 171-2. He only knew the Hsi Yuan Lu in the translation of Giles (7).

${ }^{83}$ In Sung and Yuan, this official was often called "wu tso hsing jen". See the Yuan edition of Hsi Yuan Chi $L u$, pp. 40-1.

84 Smith (1), p. 601.

${ }^{85}$ Alabaster(1) considers Chhing practice in cases of manslaughter (pp. 288ff.), murder (pp. 292ff.), suicide (pp. 303ff.) and assault (pp. 346ff.).

${ }_{86}$ A detailed account of these in relation to the various so-called "martial arts" (wu shu [165]) will be found in Lu Gwei-Djen \& Needham (5), pp. 302ff.

87 The phrase occurrs in the Hsi Yuan Chi Lu, but the charts of vital spots are given only in the Chhung Khan Pu Chu Hsi Yuan Lu Chi Chêng. Cf. Lu Gwei-Djen \& Needham (5), figs 79, 80, where the date should be corrected to the seventeenth century $A D$.
} 


\title{
Lu Gwei-Djen and Joseph Needham
}

making thirty-two in all. Modern medical science has confirmed many of these, such as the fontanelles of the skull, the occipital and cervical regions, the parts just above and below the sternum, the perineal region and scrotum. ${ }^{88}$

Then the necessary preparations for the examination of a body are described, and the examiner is warned not to be deterred by the unpleasant state of the corpse, but to make with his ostensor a systematic examination from the head downwards in every case. The examiner is advised particularly about counterfeited wounds, wounds caused by different means, such as those arising from fist blows or kicking with the foot and caused by various sorts of weapons; and asphyxial deaths such as those by strangulation and drowning. These are all given separate sections. Truly accidental drowning has to be distinguished from a person being held under the water, by weights or other means, and also from suicidal drowning. The possibility of homicidal strangulation being passed off as suicide is discussed, as is the way of distinguishing between the body of a drowned person and that of one thrown into the water after death-all these are discussed in detail. ${ }^{89}$ So, also, is the possible confusion between post-mortem and ante-mortem burning recognized; and a great deal of attention is given to the various poisons. ${ }^{90}$ The examiner is exhorted to study the place, the surroundings and the circumstances with the utmost care; and in this connection it is said that nothing can be regarded as unimportant.

Furthermore, many tests and experiments are described, some very sensible in terms of modern medical science, others containing more or less an admixture of proto-science and folk-beliefs. For example, there are some remarkable techniques for making wounds or severe contusions and bruises appear clearly on the surface of the body, as well as bone-fractures; especially the use of red-oiled umbrella paper for filtering the direct light of the sun. Under the heading 'A Discussion of Bones and Blood-vessels in the Body, and the Location of Vital Spots' ${ }^{91}$ the text ${ }^{92}$ says:

\begin{abstract}
When examining bones it is necessary that the day be clear and bright. First wash them with water, and then tie them together with hemp twine (to form a skeleton), before laying them out on a mat. Then dig a pit in the ground measuring five feet long, three feet wide and two feet deep, burning wood and charcoal in it until the ground is very hot. Clear out the ashes and pour in two pints of good wine and five pints of strong vinegar. While it is still steaming lay the bones in the pit and cover them with a straw mat, letting them remain there for two to four hours. ${ }^{93}$ When the ground has cooled, remove the mat and take the bones to a level well-lit place where they can be examined under a red silk or paper umbrella which has been waterproofed with oil (protecting them from the direct sunlight). If there are places on the bones which have been struck, then there will be traces of a red colour, and the two ends of any fracture will show a blood-red halo. Moreover if, on holding a bone up to this light, it shows a vivid red colour, then the injury was inflicted before death. If on the other hand the bones are broken, and yet show no traces of red colour, then this must have been done after death ....
\end{abstract}

${ }^{88}$ Cf. Camps \& Cameron (1).

${ }^{89}$ In the Hsi Yuan Chi $L u$, but expanded in the later works.

${ }_{90}$ The part on poisons was greatly enlarged in the Hsi Yuan Lu.

${ }^{91}$ It is in Section 18 of the original text of Sung Tzhu, Hsi Yuan Chi Lu, pp. 53-4; cf. Yang Fêng-Khun (I), pp. $45 \mathrm{ff} ., 136$.

92 Translation McKnight (1), p. 102, modified by the authors. This may be compared with the parallel passage from the Chhing edition, translated by Giles (7), p. 66 (Hsi Yuan Lu, ch. 1, pp. 49a-56b).

${ }_{93}$ This must have had the effect of cleaning the bones rather thoroughly. 


\title{
$A$ history of forensic medicine in China
}

There can be little doubt that this use of a light-filter ${ }^{94}$ was ancestral to the employment of infra-red light and similar aids in modern forensic medicine. ${ }^{95}$ It would be interesting to make some tests with oiled papers such as were used in those days, and indeed still are for umbrellas in China-this experiment has in fact been done by Wang Chin-Kuang, as we shall see.

First, however, we may take a look at the antiquity of the practice. A couple of hundred years before Sung Tzhu, an intriguing story was reported by Shen Kua [166] in his Mêng Chhi Pi Than [167] (Dream Pool Essays). He wrote: ${ }^{96}$

\begin{abstract}
When Li Chhu-Hou [168] was magistrate of Shen-hsien in Luchow, he always went to examine the injuries of corpses after fights and affrays. Boiling the dregs of wine, or ashes, ${ }^{97}$ he spread them over the bones or bodies, but often no trace of injury could be found. But an old local secretarial official knew that when injuries did not show, you should use a red-oiled silk umbrella, and look at the body or the bones in full sunlight; then if the remains were washed carefully the bruises or fractures could be seen. Li Chhu-Hou followed this advice, and found that he could see the injuries clearly, so that he proved it true. Since that time all inquest judges between the Huai River and the Yangtze invariably use this technique.
\end{abstract}

Now the very same story occurs in the Yü Hsia Chu [169] (Jade Box Records), written by Huangfu Mei [170] about $880 \mathrm{AD}$, so there can be very little doubt that the procedure of "examining corpses in red light" (hung kuang yen shih [171]) goes back at least as far as the Thang. Later on the account recurs in Chêng Kho's [172] Chê Yü Kuei Chien [44] (Magic Mirror for Solving Doubtful Criminal Cases) of AD 1133, and eventually it found its way into Fang I-Chih's [173] Wu Li Hsiao Shih [174] (Small Encyclopaedia of the Principles of Things) of $1643 .^{98}$

All these references were unearthed by Wang Chin-Kuang, ${ }^{99}$ and he also made practical experiments with light filters, finding that red glass or red nylon, which let through only the longest wavelengths of visible light (around $6500 \AA$ ), have effects similar to those stated. Such a light will bring out even the deepest superficial veins, and bruises otherwise invisible appear purplish in colour.

We also find in the book a great deal of osteological and anatomical description. In connection with bones, the text describes a test of genetic relatedness carried out by dropping blood from a living individual on to the bones of a dead one, and seeing whether it sinks in or not. The Hsi Yuan Chi Lu text says: ${ }^{100}$

To identify relatives using the technique of dripping blood on bones, you have for example A, a deceased father or mother, whose bones are available. Someone, B, comes forward claiming to be a son or daughter. How are you going to find out? Let the claimant cut himself or herself slightly, drawing one or two drops of blood, and let them drip on to the bones of the parents. Then if they are indeed son or daughter, the blood will sink into the bone, but if B is not, it will not do so. This is what is meant by the common saying "dripping blood to establish relationship".

${ }^{94}$ Another use of a light-filter umbrella occurs in Section 8 (p. 41), translated by McKnight (1), p. 81 .

${ }^{95}$ See for instance Walls (1), pp. 69ff.

${ }^{96} \mathrm{Ch}$. 11, p. 10a, b, translated by the authors. The passage is item 209 in the edition of Hu Tao-Ching (1), vol. 1 , p. 429.

97 This must have been slightly alkaline, removing all oil and whitening the bones.

${ }^{98}$ Ch. 3, p. $24 a, b$.

99 Wang Chin-Kuang (3).

100 The Yuan version of $H$ si Yuan Chi $L u$, Sect. 18, p. 53, translated by McKnight (1), pp. 101-2, modified by the authors. 


\section{Lu Gwei-Djen and Joseph Needham}

The Hsi Yuan Lu says: ${ }^{101}$

The bones of parents may be identified by their children in the following manner. Let the experimenter cut himself or herself with a knife and cause the blood to drip on to the bone. Then if the relationship is an actual fact, the blood will soak into the bone, otherwise it will not. N.B. Should the bones have been washed with salt water, even though the relationship exists, yet the blood will not soak in. This is a trick to be guarded against beforehand.

This test ( $t i$ hsüeh [175]) must be very much older than the thirteenth century AD because it occurs also in the folk ballad Mêng Chiang Nü [176] which deals with events of the third century $\mathrm{BC}$, and must itself be at least Thang and probably much older. ${ }^{102}$ It certainly goes back to the sixth century AD, because it is mentioned in the biography of Hsiao Tsung [177] Prince of Yü-Chang [178]; and it was known in the third century AD because it comes in the story of Chhen Yeh [179] who identified the body of his brother in this way after a shipwreck. ${ }^{103}$

Possibly these procedures had no rational basis, but one can never feel absolutely certain, because some immunological property might be involved; after all, blood groups are used today in tests of relatedness. ${ }^{104}$ It may be dangerous to write such things off as superstition, because one sometimes finds, in the later progress of science, that there may be explanations which one did not see at first. ${ }^{105}$ In any case, this ancient test would certainly be ancestral to the determination of genetic relationship by immunological means today. ${ }^{106}$

There is also an interesting statement about the geo-botanical effects on vegetation after a cremation has taken place, for example, in a particular part of a field: ${ }^{107}$

Where a body has been burned, the grass will be darker in hue, more luxuriant and taller than that surrounding it; and it will not lose these characteristics for a long time, because the fat and grease of the body sinking down to the roots of the grass brings about such results. If the spot is on a hill or a wild place where vegetation is very luxuriant, then you must look for a growth about the height of a man. If the burning took place on stony ground, the crumbly appearance of the stones must be your guide; this makes the process much easier.

The Hsi Yuan Lu also describes death caused by certain diseases such as rabies ${ }^{108}$ or tetanus, rather easy to recognize; as well as poisoning by all kinds of substances,

${ }^{101}$ Hsi Yuan Lu, ch. 1, pp. 57a-60b, translated Giles (7), p. 73.

102 But in the ballad the test was done as between husband and wife, which Sung Tzhu and all the later medico-legal experts knew was impossible. The test could only establish genetic connection. Later on the technique was extended to brother-sister relationships; the test was to see if the drops of blood "congealed" (i.e. precipitated) in water or not (Chhung Khan Pu Chu Hsi Yuan Lu Chi Chêng, ch. 1, p. 55a). The water had to be absolutely pure. The ballad may well serve as evidence that the test was known, however.

${ }^{103}$ See Chung Hsü (2), who enumerates other cases as well. The former record is in the Liang Shu, ch. 55, p. 2a; the latter in the Kuei-Chi Hsien Hsien Chuan [180] by Hsieh Chhêng [181].

${ }^{104}$ We were informed by our friend the late Professor Hermann Lehmann that, apart from the blood group $\mathrm{O}$, all the others would precipitate on the bone; while if there was relatedness the others would in fact sink in, assuming that the bone was fairly recent. On the agglutinogens and erythrocyte antigens known today, and used in forensic medicine, see Walls (1), pp. 133ff., $155 \mathrm{ff}$.

${ }_{105}$ In the Hsi Yuan Lu editions, many reported cases testify to the effectiveness and accuracy of the tests (Chhung Khan Pu Chu Hsi Yuan Lu Chi Chêng, ch. 1, pp. 57a and following).

106 Tests of relationship are now done by DNA "finger-printing": see Jeffreys, Brookfield \& Semenoff (1) and Hill, Jeffreys, Brookfield \& Semenoff (1).

107 Chhung Khan Pu Chu Hsi Yuan Lu Chi Chêng, ch. 1, pp. 61b, 62a, translated Giles (7), p. 74. There is no equivalent in the original Yuan edition. The section is called 'Chien Ti' [182], 'Examination of the Ground'.

${ }_{108}$ Chhung Khan Pu Chu Hsi Yuan Lu Chi Chêng, ch. 3, p. 19a, ch. 4, p. 17a; translated Giles (7), pp. 92, 103. 


\section{A history of forensic medicine in China}

including incidentally the recommendation of animal experiments with food suspected of being poisoned. ${ }^{109}$ As we shall show later on, the carrying out of actual experiments was rather characteristic of Chinese forensic medicine right back to the Han - a matter of no mean interest. We have, too, a description of carbon monoxide poisoning in the book. ${ }^{110}$ This would of course have been quite likely to arise in traditional times because of the use of charcoal for heating indoor rooms. ${ }^{111}$ Heating was always rather rudimentary in medieval China, and charcoal pans (huo phan [183]) were used, as indeed they still are today in many parts of the country. Again, the $\mathrm{Hsi}$ Yuan $\mathrm{Lu}$ also tells us about the signs of poisoning with arsenic and soda and other favourite recourses of medieval suicide. On the other hand, the book contains much on resuscitation and reanimation, including what we might now call the "kiss of life", 112 and getting respiratory reflexes to start again. ${ }^{113}$ The book also has much to say on haemostatic substances, antidotes, emetics and all kinds of first-aid practices in cases of poisoning. All the recipes belong, of course, to the late seventeenth century AD.

Evidently the Khang-Hsi edition was remarkably well informed on medical matters. The writers knew the medical names of diseases, the terms for drugs, and were aware of their uses. They have a number of references to chhi [185], the "pneuma" spoken of so often by the physicians. Furthermore, they mentioned a number of medical books such as the Ching Yen Fang [186] (Tried and Tested Prescriptions) finished by Chang Shêng-Tao in the Northern Sung, AD 1025. They also referred to a $W u$ Tsang Shen Lun [187] (Subtle Discourse on the Five Solid Viscera); this was perhaps the title of a chapter in some version of the Huang Ti Nei Ching [188], but if it was a separate book or a tractate, it must have appeared earlier than the Khang-Hsi reign-period. They also drew on an older medico-legal work, the Nei Shu Lu [36] (Record of Conscientious and Merciful Judgements), the writer of which is unknown. Neither of these titles appear to be listed by the bibliographical encyclopaedists.

\section{SOME COMPARISONS WITH EUROPE}

And so we come back in the end to the point at which we started, namely the development of forensic medicine in Europe. ${ }^{114}$ There was not much role for legal medicine in ancient Greece, though perhaps more in ancient Rome. But in Hellenistic Egypt there were "public physicians" giving reports on dubious cases to the local authorities. ${ }^{115}$

But if Greece and Rome did relatively little in this direction, one cannot quite say the same of the Byzantines, because in the Justinian enactments, made between 529 and 564, we find many striking new things. The Code of Justinian provided for the regulation of the practices of medicine, surgery and midwifery; the classes of physicians that were to be recognized; the limitation of their numbers in any one town; and the

${ }^{109}$ Chhung Khan Pu Chu Hsi Yuan Lu Chi Chêng, ch. 3, p. 36b, translated Giles (7), p. 94.

110 Chhung Khan Pu Chu Hsi Yuan Lu Chi Chêng, ch. 3, p.52a, translated Giles (7), p. 97.

111 Especially the Khang [184], a platform serving as a bed or for sitting on, particularly in North China.

112 Chhung Khan Pu Chu Hsi Yuan Lu Chi Chêng, ch. 4, p. 2a, b, translated Giles (7), p. 98.

113 Chhung Khan Pu Chu Hsi Yuan Lu Chi Chêng, ch. 4, pp. la and following, translated Giles (7), pp. 98ff.

114 See Ackerknecht (2); Gorsky (1); Greene (1); Kerr (1), pp. $340 \mathrm{ff}$.

115 See Amundsen \& Ferngren (1), who consulted a profusion of papyrus fragments. 


\section{Lu Gwei-Djen and Joseph Needham}

penalties to be imposed for malpractice. ${ }^{116}$ The status and function of the medical expert in connection with legal procedures comes out more clearly than ever before in the famous phrase Medici non sunt proprie testes, sed majus est judicium quam testimonium - which Sydney Smith has freely interpreted as meaning that the medical expert is not used to proper or greatest advantage if he is regarded simply as a witness appearing for one side or the other; his function is rather to assist the judiciary by impartial opinion based on specialized knowledge. ${ }^{117}$ As he says, this dictum is still true today.

The Justinian Code enjoined the co-operation of medical experts in a considerable variety of legal problems, which included the determination of the condition of pregnancy, cases involving sterility, impotence or legitimacy, cases of rape, and of poisoning, cases involving the problem of survivorship, as well as cases complicated by the question of mental disease or other comparable circumstances. ${ }^{118}$ Smith was probably right in saying that the Justinian enactments may be held to represent the highest point of achievement in the way of defined forensic medicine in the ancient world. But still there was no systematic treatise.

On the other hand, very little of this seems to have been incorporated in the legal systems of the European Middle Ages. In the best book on The mediaeval coroner, by Hunnisett, ${ }^{119}$ you will look in vain in the index for anything indicating medical evidence; the words "physician", "medico-legal", or "doctor" simply do not occur. Yet it covers the period approximately from the Norman Conquest to the end of the fifteenth century.

This period of darkness seems to have ended in 1507 when the Bishop of Bamberg and John of Schwarzenberg issued a new, comprehensive, and systematized penal code which was soon adopted by a number of the neighbouring German states as well. Then in 1532 and 1553, developing from the Bamberger Code, there appeared the still more influential Constitutio criminalis carolina or Caroline Code, proclaimed by the Emperor Charles V as the code of law henceforth to be observed throughout the empire. In both these early Germanic codes, it is for the first time clearly and definitely laid down that expert medical testimony must be obtained for the guidance of the judges in cases of murder, wounding, poisoning, hanging, drowning, infanticide, abortion, and in other circumstances involving the person. ${ }^{120}$

Now it can hardly be a coincidence that between these two codes, in 1543, Andreas Vesalius published his splendid monograph De fabrica humani corporis. ${ }^{121}$ Vesalius

${ }^{116} \mathrm{Cf}$. Thomas (1,2); Scott (1); Pothier \& Bréard-Neuville (1); and Tissot (1).

117 Smith (1), p. 601. But the sentence is not in the Corpus juris civilis of Justinian, as Professor Peter Stein has informed us after a thorough search. It may well come from some later commentary, but the origin has not been indentified as yet.

118 In general one gets the impression that Roman and Byzantine law was more concerned with property, inheritance, wills, guardianship, and the like, than with criminal actions leading to inquests. In China, on the other hand, law seems to have been much more criminal law, while all the other matters were attended to at family and clan meetings, guild assemblies, and so on. Only if these were unable to reach a decision did a matter get taken to the courts. Of course, if an affray resulted from disagreement, then the courts would be appealed to.

119 Hunnisett (1).

${ }^{120}$ Smith (1), p. 602.

121 See Singer (25), pp. $110 \mathrm{ff}$. 
paved the way for all the autopsies of later times, for he put his own hand to the business of dissection, doing away with the demonstrators and ostensors of former times. He was also a great creative artist, and the plates which he published were extraordinarily influential. Although Vesalius died in 1565, he was certainly one of those who, together with Galileo, brought modern science into being. ${ }^{122}$

It was in this atmosphere that medical scientists began to realize that their evidence would be indispensable in guiding judges to right judgments. Perhaps the first to realise this was the eminent French surgeon Ambroise Paré, whose 'Traicté des rapports, et du moyen d'embaumer les corps morts' was never published separately, but appeared in his collected works Les oeuvres de M. Ambroise Paré, Conseiller et Premier Chirurgien $d u$ Roy . ..., published at Paris in $1575 .{ }^{123}$ It was reprinted many times thereafter and translated into English in 1634, where the individual treatise is entitled 'How to make reports, and to embalme the dead'. The first comprehensive treatise on medico-legal matters was, however, by an Italian physician, Fortunato Fedele, whose De relationibus medicorum appeared at Palermo in 1602. Although it was contemporary with that of Wang Khên-Thang, ${ }^{124}$ the conditions of intercourse at that time were such that neither of them had any idea of the existence of the other, let alone what he was doing.

Before long the book of Fedele was put into the shade by a much more impressive work, that of Paolo Zacchia, who wrote his Quaestiones medico-legales at Rome between 1621 and 1635. In this book he deals with all the questions likely to arise in the conduct of court cases to the perplexity of judges and their assistants. The book long maintained a great reputation, though the knowledge of anatomy and physiology was still very inferior; in any case, the science of forensic medicine had certainly now been born. ${ }^{125}$ All the European countries henceforward competed in the study of this subject. One may mention the German book of Rodericus à Castro, Medicus politicus, published at Hamburg in 1614; and the French one of Nicolas de Blégny, La doctrine des rapports de chirurgie, published at Lyon in 1684. By now the Harveian doctrine of the circulation of the blood was becoming generally accepted, and medicine was entering its modern phase. We may be dispensed, therefore, from following the further history of the subject into modern and contemporary times.

It now only remains to ponder McKnight's interesting suggestion that the Chinese example of Sung Tzhu might have had some influence in late medieval Europe, especially Norman England. ${ }^{126}$ The law of the Anglo-Saxons and Germans in early

\footnotetext{
122 Gross anatomy had of course been well developed in China since ancient times; the weights of organs and the lengths of blood-vessels were given in the Huang Ti Nei Ching. Cf. Lu Gwei-Djen \& Needham (5), p. 33; see also $S C C$, Section 43. We suspect that it was not so much the lack of anatomy that made Chinese forensic medicine fall behind that of the West in the nineteenth century, as the lack of microscopy, physiology, and biochemistry.

123 See Doe (1), p. 107.

124 See above. The fact that these two treatises appeared at the same time would seem to constitute yet another instance of the phenomenon that although the Scientific Revolution happened only in Europe, not in China, there are many remarkable examples of the ethos of modern science arising spontaneously in Chinese society during the late sixteenth and seventeenth centuries. This has been discussed in Needham (89).

125 Smith (1), pp. $602 \mathrm{ff}$.

${ }^{126}$ McKnight (1), pp. 24-5.
} 
times had indeed required rather precise descriptions of wounds, because of the monetary recompense to be paid for them; and all the members of the court were supposed to view the wounds. But the English system forms a closer parallel. From 1194 onwards, it became customary that the "crowner" selected in each county held inquests on all those who had died through homicide or accidentally. A jury was empanelled and an oath exacted from the foreman of the jury, and all this was done coram populo. Time-limits for deaths from wounds were established, but the victim was not handed over, as in China, to his assailant to be cured if possible. McKnight adds that the resemblance of the English practices to the Chinese becomes even more striking when we read the list of faults of which coroners were accused. It was said that among other misdeeds, they often sent proxies to the viewing, delayed or tarried in their work, accepted bribes, or entered information into the record which either did not derive from the inquest or was patently false.

Since at this time Norman England was in quite close contact with the Norman Kingdom of Scicily, where Roger II (1098-1154) and Frederick II (1194-1250) were both rulers extremely interested in intellectual matters, there might have been some connection, especially as the Sicilian court was in close contact with the Islamic countries further east. Twenty years ago, we suggested that the idea of qualifying examinations for physicians came to Norman Sicily, and hence to Salerno and all Europe, from China by way of Baghdad; ${ }^{127}$ for it was there, in AD 931, that the Caliph instituted examinations in competence for all qualifying medical students. Thus in the present case, we would need to know what were the practices in Arabic lands regarding the investigation of cases of homicide, accidental death, or suicide. Until more is known about this, we cannot say much on the passage of any influence from China, although it would certainly have had to have been a good deal later than the idea of qualifying examinations in medicine.

Last of all, we must clear up an apparent contradiction in what has gone before. On the one hand, we said that the relative ignoring of medical evidence in cases of death or injury was characteristic of the Middle Ages in Europe, before the rise of modern science. Yet a commentary on the Justinian Code had laid down that the medical expert did indeed have a function, that of advising the judge with an impartial interpretation and opinion. This becomes less paradoxical when one appreciates that the former statement applies especially to Northern Europe, while the Byzantine attitude was perpetuated later on in the South, especially in Italy. It did not bear fruit, however, until the thirteenth century, when Bologna was the first city in Europe to establish "a service of expert medical investigation in all cases of offences against the human being", in $1252 .{ }^{128}$ It was a striking coincidence that this should have been so soon after the appearance of Sung Tzhu's Hsi Yuan Chi Lu of 1247 at the other end of the Old World-but of course the Bologna doctors never thought of preparing a systematic treatise on the subject. The relevant statutes were updated in 1262, and again in 1265 and 1288 , but the function of the physicians seems to have been limited to testifying whether or not a wound was mortal, and also whether wounds were inflicted

127 The most probable date for the beginning of Chinese qualifying examinations in medicine is $\mathrm{AD} 493$.

128 See Simili (1, 2, 3); Munster (1); Samoggia (1). 


\section{A history of forensic medicine in China}

before or after death. This was all rather unsophisticated compared with Sung Tzhu's disquisitions on the differentiation of murder from suicide by hanging, ${ }^{129}$ or death by burning ${ }^{130}$ or drowning, ${ }^{131}$ or suicide and murder with edged weapons. ${ }^{132}$ The same provisions occur in the city laws of Freiburg im Breisgau, but as one would expect, only a couple of hundred years later, in 1407 and $1466 .{ }^{133}$ And it was at this time that autopsies began to be performed in Italy, as part of the slow development of anatomical knowledge. By the sixteenth century modern science was beginning to develop both south and north of the Alps; yet it was no coincidence that the first book on poisons, Battista Codronchi's De morbis veneficis, was published in Venice in 1595. The tide of modern science was now rising, as we have noted already in the case of the books of Fortunato Fedele and Paolo Zacchia, founders of modern forensic medicine. It may well be that China was in the circuit which led, over the centuries, to this entirely new level of accuracy and understanding.

129 Sects. 19, 20.

130 Sect. 26.

131 Sect. 21.

132 Sects. 23, 24.

${ }^{133}$ See Volk \& Warlo (1).

\section{LIST OF OLD CHINESE REFERENCES}

Note. Each entry gives particulars in the following order: $(a)$ title; $(b)$ translation of title; $(c)$ crossreference to closely related book, if any; $(d)$ dynasty; (e) date; $(f)$ name of author or editor; $(g)$ title of other book, if the text of the work now exists only incorporated therein, or references to sinological studies of it; $(h)$ references to translations, if any, given by the name of the translator in the 'List of Western references'; $(i)$ notice of any index to the book.

\section{Chê Yü Kuei Chien}

Magic Mirror for Solving (Doubtful Criminal) Cases, or, Discerning False Accusations.

Sung, $c$. AD 1133, repr. 1261 with postface by Chao Shih-Tho.

Chêng Kho.

Cf. Sung Ta-Jen (9).

\section{Chê Yü Chih Yen}

Collection of Difficult Cases.

Chhing, 18th century AD.

Chhen Shih-Khuang.

\section{Chen Chiu Chia I Ching}

Treatise on Acupuncture and Moxibustion.

S/Kuo and Chin, finished some time between AD 256 and the author's death in 282 .

Huangfu Mi.
Chi Chiu (Phien)

Handy Primer [orthographic word-lists intended for verbal exposition, connected with a continous thread of text and having some rhyme arrangements].

$\mathrm{C} / \mathrm{Han}$, between 48 and $33 \mathrm{BC}$.

Shih Yu, with seventh-century commentary by Yen Shih-Ku, and thirteenth-century commentary by Wang Ying-Lin.

Chien Ku Thu Ko

Illustrated Procedure for Examining Bones, with Osteological Diagrams; also entitled 'Illustrated Procedure for Examining Bones as Standardised by the Board of Justice'.

Chhing, AD 1770.

Tsêng Fu.

Included in Chhung Khan Pu Chu Hsi Yuan Lu Chi Chêng.

Chien Yen Chêng Pei Jen Hsing Thu

Anterior and Posterior Outline Diagrams of the Human Body, for Use in Inquest Examinations.

Sung, AD 1204 (Hunan and Kuangsi).

Writer unknown.

Chien Yen I Lai Chhao Yeh Tsa Chi

Miscellaneous Records of Court Officials and Common People since the Chien-Yen reignperiod (AD 1127 to 1130).

Sung, ca. AD 1220.

Li Hsin-Chhuan. 


\section{Lu Gwei-Djen and Joseph Needham}

Chien Yen Ko Mu

Inquest Forms to be Filled In (during the examination of the corpse).

Sung, AD 1174.

Chêng Hsing-I.

Chien Yen San Lu

Three Books on Inquest Procedure.

1811-12.

Cf. Chuko-Chi (l), p. 93; Sung Ta-Jen (9), p. 280.

\section{Ching Yen Fang}

Tried and Tested Prescriptions.

Now extant only in quotations.

Sung, AD 1025.

Chang Shêng-Tao.

Chuang Tzu (= Nan Hua Chen Ching).

The Book of Master Chuang.

Chou, c. 290 BC.

Chuang Chou.

Tr. Legge (5); Fêng Yu-Lan (5); Lin Yü-Thang (1).

Yin-Tê Index no. (suppl.) 20.

Chhung Hsiu Phi Ling Chih

Local History and Geography of Chhangchow.

Sung, AD 1268.

Shih Nêng-Chih, assisted by Sung Tzhu.

Huang Ti Nei Ching, Su Wên

The Yellow Emperor's Manual of Corporeal (Medicine); Questions (and Answers) about

Living Matter [clinical medicine].

(Cf. Pu Chu Huang Ti Nei Ching, Su Wên).

Chou, remodelled in Chhin and Han, reaching

final form $c$. second century BC.

Writers unknown.

Ed. \& comm., Thang (AD 762), Wang Ping; Sung (c. AD 1050), Lin I.

Partial trans. Hübotter (1), chs. 4, 5, 10, 11, 21; Veith (1); complete, Chamfrault \& Ung Kang-Sam (1).

\section{Hsi Yuan Chi Lu}

Collected Records of the Washing Away of Unjust Imputations, or Wrongs [treatise on forensic medicine, commonly known as $\mathrm{Hsi}$ Yuan $L u]$.

Sung, AD 1247.

Sung Tzhu.

Partial trans. H. A. Giles (7); McKnight (1); cf. Balazs \& Hervouet (1), p. 186.
Hsi Yuan Chi Lu Fu-Kho Yuan-Khan-Pên

A Reprint of the Yuan Edition of $\mathrm{Hsi}$ Yuan Chi Lu.

First written by Sung Tzhu, AD 1247.

Chhing, AD 1807.

5 chapters.

Hsi Yuan Lu Chi-Chêng

Collected Verifications of the Hsi Yuan Chi Lu.

Chhing, AD 1736.

Wang Yu-Huai.

Hsi Yuan Lu Chien Shih

A Commentary on the 'Washing Away of Unjust Imputations, or Wrongs'.

Ming, $c$. AD 1602

Wang Khên-Thang.

Hsiao Tai Li Chi.

See $\mathrm{Li}$ Chi.

Hsin Chu Wu Yuan Lu

The 'Cancelling of Wrongs, or False Charges' Newly Commented.

Korea, AD 1438, printed 1440, 1447.

Preface by Liu I-Shun.

Tshui Chih-Yün, Li Shih-Hêng, Pien Chiao \& Chin Wang.

I Yü Chi

Collection of Doubtful Criminal Cases, or, Redressing Wrongs among the People.

See I Yü Chhien Chi; I Yü Hou Chi.

I Yü Chi Hsü Pien

Further Collection of Doubtful Criminal Cases.

Ming, AD 1542.

Chang Chin.

I Yü Chien (or I Yü Chi Chien)

A Commentary on the Collection of Doubtful Criminal Cases.

Chhing, c. AD 1684.

Chhen Fang-Shêng.

4 chapters.

I Yü Chhien Chi

First Collection of Doubtful Law Cases.

Wu Tai, between 907 and 940 AD.

Ho Ning.

\section{Yü Hou Chi}

Second Collection of Doubtful Law Cases.

Su Tai, between 940 and 960 AD.

Ho Mêng.

Kuei-chi Hsien Hsien Chuan

Biographies of the Former Sages of Kuei-Chi. San Kuo, third century AD.

Hsieh Chhêng. 


\section{$A$ history of forensic medicine in China}

Li Chi [Hsiao Tai Li Chi.].

Record of Rites [compiled by Tai the Younger].

(Cf. Ta Tai Li Chi).

Ascr. C/Han, c. 70 to $50 \mathrm{BC}$, but really $\mathrm{H} / \mathrm{Han}$, between $\mathrm{AD} 80$ and 105, though the earliest pieces included may date from the time of the Analects (c. 465 to $450 \mathrm{BC}$ ).

Attrib. ed. Tai Shêng; actual ed. Tshao Pao.

Trans. Legge (7); Couvreur (3); R. Wilhelm (6).

Yin-Tê Index, no. 27.

\section{Liang Shu}

History of the Liang Dynasty.

Thang, AD 629.

Yao Chha and his son Yao Ssu-Lien.

\section{Lü Li Kuan Chiao Chêng Hsi Yuan Lu}

Book of the 'Washing Away of Wrongs' collated and verified by the Office of Laws and Regulations.

Chhing, AD 1662, 1694; the Chien Ku Thu Ko (Illustrations for Examining Bones) was added in 1770 by decree.

Writers unknown.

\section{Lü Shih Chhun Chhiu}

Master Lü's Spring and Autumn Annals [compendium of natural philosophy].

Chou (Chhin), 239 вC.

Written by the group of scholars gathered by Lü Pu-Wei.

Tr. R. Wilhelm (3).

Chung-Fa Index, no. 2.

Lun Yü

Conversations and Discourses (of Confucius) [perhaps Discussed Sayings, or Selected Sayings]; Analects.

Chou (Lu), c. 465 to 450 BC.

Compiled by disciples of Confucius (chs. 16, 17,18 and 20 are later interpolations).

Tr. Legge (2); Lyall (2); Waley (5); Ku HungMing (1).

Yin-Tê Index no. (suppl.) 16.

\section{Mêng Chhi Pi Than}

Dream Pool Essays.

Sung, AD 1086; last supplement dated 1091. Shen Kua.

Ed. Hu Tao-Ching (1); cf. Holzman (1).

\section{Mêng Chiang Nü}

The Ballad of Mêng Chiang Nü Weeping at the Great Wall.

? Thang or pre-Thang, perhaps Chhin.

Tr. Needham \& Liao Hung-Ying (1).
Ming Yuan Shih Lun

Discourse on Cases of the Bringing to Light of Unjust Imputations.

N/Chhi, sixth century AD.

Hsü Chih-Tshai.

Now extant only in quotations.

Nei Shu Lu

Record of Conscientious and Merciful Judgments.

Sung, before AD 1247.

Writer unknown.

McKnight (1), p. 29; Yang Fêng-Khun (l), p. 174.

\section{Pao Chien Phien}

Essays of Precious Reflections.

Chhing.

Also added to Chhê Yü Kuei Chien; and included in Chhung Kan Pu-Chu HYL ChiChêng, a reprint in 1898.

Fang Ju-Chhien, ed.

1 vol.

Phing Yuan Lu

Pacification by the Redressing of Wrongs.

Sung, perhaps $c$. AD 1255.

Probably Chao I-Chai.

Shih Hsiang Pi Lu

Secret Records of Stone Fragrance (so-called because it was in the collection of Ching Shih-Hsiang).

Chhing.

Writer unknown, revised by Chung Chên-Lü; later, by Chang Hsi-Fan.

Added to Chê Yü Kuei Chien, also Pu Chu Hsi Yuan Lu Chi-Chêng (1898 edition).

\section{Sung Hui Yao Kao}

From the Yung-Lo Ta Tien.

Drafts for the History of the Administrative Statutes of the Sung Dynasty.

Sung.

Collected by Hsü Sung (1809).

\section{Ta Ming Lü Hsing Shu Chü Hui}

Assembly of Books on the Criminal law based on the Ming Dynasty Legal Code.

Ming.

Writer unknown.

\section{Ta Ming Lü Li Chih Chün Chhi Shu}

Collection of Meritorious Techniques for presenting Cases to the Emperor in the Ming Dynasty Legal Code.

Ming.

Chu Ching-Hsün. 


\section{Lu Gwei-Djen and Joseph Needham}

Thang Yin Pi Shih

Parallel Cases from under the Pear-tree [comparable legal cases solved by eminent judges].

Sung, AD 1211, printed 1222, 1234.

Kuei Wan-Jung.

Tr. van Gulik (6).

Thang Yin Pi Shih Hsü Pien

Continuation of 'Parallel Cases from under the Pear-Tree'.

Ming.

$\mathrm{Wu} \mathrm{Na}$.

Tsêng Hsiu Wu Yuan Lu Ta Chhüan

The Complete 'Cancelling of Wrongs, or False Charges' Enlarged and Revised.

Korea, AD 1796.

Chü Yün-Ming.

2 vols.

Tu Lü Pei Hsi

Reading the Law Whilst Adorned with a Bodkin.

Chhing, AD 1764.

Explained the Chhing law under various sections.

Includes Hsi Yuan Lu and Hsi Yuan Lu Pu, incorporating Chiu Chi Fang.

Wang Ming-Tê.

8 chapters.

Wu Li Hsiao Shih

Small Encyclopaedia of the Principles of Things.

Ming and Chhing, finished by AD 1643 , sent to his son Fang Chung-Thung in 1650, finally printed 1664.

Fang I-Chih.

Cf. Hou Wai-Lu $(3,4)$.

$W u$ Tsang Shen Lun

Subtle Discourse on the Five Solid Viscera [perhaps the title of a chapter in some version of Huang Ti Nei Ching].

Sung, before AD 1247.

Writer unknown.

McKnight (1), pp. 29, 85.
Wu Yuan Lu

The Cancelling of Wrongs (i.e. False Charges)

[treatise on forensic medicine].

Yuan, AD 1308.

Wang Yü.

Wu Yuan Lu Chi Chu

Edited Annotations for the $W u$ Yuan $L u$.

Korea.

Compiled in Yuan by Wang Yü; revised in Ming by Wang Yu.

Tshui Chih-Yün.

Wu Yuan Lu Shu

The 'Cancelling of Wrongs, or False Charges' Discussed.

Japan, AD 1768; printed 1788; reprinted 1799.

Preface by Kawai Jinhyōe (AD 1736).

Yü Chu Pao Tien

Jade Candle Precious Repository (of Notes).

Sui, c. AD 595.

Tu Thai-Chhing.

In Lu Hsin-Yuan (l), ch. 22.

Yü Hsia Chi

The Jade Box Record.

Thang, $c$. AD 880.

Huangfu Mei.

Yü Thang Hsien Hua

Leisurely Talks in the Academy.

Wu Tai $c$. AD 950.

Ho Mêng.

Yüeh Ling

Monthly Ordinances (of the Chou Dynasty).

Chou, between seventh and third centuries BC.

Writers unknown.

Incorporated in the Hsiao Tai Li Chi and Lü Shih Chhun Chhiu, q.v.

Tr. Legge (7); R. Wilhelm (3).

Yüeh Ling Chieh

Commentary on the 'Monthly Ordinances (of the Chou Dynasty)'.

Sung $c$. AD 1211.

Chang Fu.

\section{LIST OF MODERN CHINESE AND JAPANESE REFERENCES}

Anon. (202)

Chung-Kuo Ku-Tai Kho Chi Chhêng-Chiu.

Achievements of Science and Technology in

Ancient and Medieval China.

Chung-Kuo Chhing-Nien, Peking, 1978.
Anon. (259)

Shui-hu-ti Chhin Mu Chu Chien.

The Bamboo Strips from the Chhin Tomb at Shui-hu-ti (near Yün-mêng).

Wên $W u$ Press, Peking 1977. 


\section{$A$ history of forensic medicine in China}

Anon. (260)

Yün-Mêng Chhin Chien Shih Wên.

Explanation of the (Laws of the Chhin State) written on the Bamboo Slips discovered in the Chhin Tomb near Yün-mêng.

Wên $W u$ [History and Archaeology], 1976, (no. 6), 11, (no. 7), 1, (no. 8), 27.

Anon. (261)

Shui-hu-ti Chhin Mu Chu Chien.

The Bamboo Slips from the Chhin Tomb at Shui-hu-ti (near Yün-mêng).

Wên $W u$, Peking, 1978.

Chang Hsien-Chê \& Tshai Kuei-Hua (l)

'Hsi Yuan Lu' Yen-Ko Su.

The History of the First Medico-Legal Book 'The Washing Away of Unjust Imputations' (AD 1247).

New Med. J. (Taiwan), 1971, 1 (no. 1), 29.

Chi Hsün (l)

Yün-Mêng Shui-Hu-Ti Chhin Chien Kai Shu.

A General Account of the pre-Chhin Writings discovered at Shui-hu-ti near Yün-mêng.

Wên $W u, 1976$ (no. 6).

Chia Ching-Thao (I)

Chung-Kuo Ku-Tai Fa-I Chien-Yen ti Fên Kung.

On the Division of Duties between the Physicians and the Magistrate's Ostensors in Ancient and Medieval China.

Chung-Hua I Shih Tsa Chih [Miscellany of the History of Medicine in China], 1982, 12 (no. $1), 13$.

Chia Ching-Thao (2)

Chung-Kuo Ku-Tai Fa-I Hsüeh Yü Hsing Chen Shu Chi Tsai Chao Hsien Yü Jih-Pên.

On the Transmission of Ancient and Medieval Chinese Books on Forensic Medicine and Jurisprudence to Korea and to Japan.

Chung-Hua I Shih Tsa Chih [Miscellany of the History of Medicine in China], 1981, 11 (no. 3), 148.

Chia Ching-Thao (3)

Chung-Kuo Ku-Tai Fa-I-Hsüeh Fa Chan Shih; 'Hsi Yuan Chi Lu'.

The Development of Forensic Medicine in Ancient and Medieval China, with special reference to the 'Washing Away of Unjust Imputations' (AD 1247).

Shanghai, 1981.

Chia Ching-Thao \& Chang Wei-Fêng ( $l$ ) Yün-Mêng Chhin Chien yü Fa-I-Hsüeh.

Medicine, especially Forensic, on the Chhin period Bamboo Slips found at Yün-mêng.

Chung-Hua I Shih Tsa Chih [Miscellany of the History of Medicine in China], 1980, 10 (no. 1), 15 .
Chuko Chi (l)

Sung Tzhu Chi Chhi 'Hsi Yuan Chi Lu'.

Sung Tzhu and his (Medico-Legal) Book 'The

Washing Away of Unjust Imputations'.

Li Shih Yen Chiu [J. Hist. Research], 1979 (no.

4), 87; also in Yang Fêng-Khun (l) q.v., p. 170.

Chung Hsü (I)

Chung-Kuo Fa-I Hsüeh Shih.

A History of Forensic Medicine in China.

Chung I Tsa Chih [J. Chinese Traditional

Med.], 1956, no. 8, 445; no. 9, 501.

Chung Hsü (2)

Yu Kuan O Kuo Fa-I-Hsüeh Shih Fang Mien Erh Shih.

On Two Subjects (Blood test, and the Ostensor) in the History of Legal Medicine in China.

I Shih Tsa Chih [Chinese Med. Hist. Journ.], 1957, no. 4, 286.

Chhen Khang-I ( $I)$

Chung-Kuo Fa I Hsüeh Shih.

A History of Forensic Medicine in China.

I Shih Tsa Chih [Chinese Med. Hist. Journ.], 1952, 4 (no. 1), 1.

Chhen Pang-Hsien ( $I$ )

Chung-Kuo I-Hsüeh Shih.

History of Chinese Medicine.

Com. Press, Shanghai, 1937, 1957.

Chhen Shêng-Khun ( $I$ )

Chung-Kuo Chhuan-Thung I-Hsüeh Shih.

History of Traditional Chinese Medicine.

Shih Pao Shu Ssu, Taipei, 1979.

Chhen Shih-Hsien ( $I$ )

Fa-I Ku-Hsüeh.

Osteology in Forensic Medicine.

Chhün Chung, Peking, 1983.

Hou Tshun Hsien-Sêng ( $I$ )

Hou Tshun hsien-sêng Ta Chhüan Chi.

$\mathrm{Mr}$ Hou-Tshun's Great Collection of Memorabilia.

Chhing, after 1800.

Hou Wai-Lu (3)

Fang I Chih-Chung-Kuo ti Pai Kho Chhüan Shu Phai Ta Chê-Hsüeh Chia.

Fang I-Chih-China's Great Encyclopaedist Philosopher.

LSYC, 1957 (no. 6) 1; 1957 (no. 7), 1.

Hou Wai-Lu (4)

Shih-liu Shih-Chi Chung-Kuo ti Chin-Pu ti Chê-Hsüeh Ssu-Chhao Kai-Shu.

Progressive Philosophical Thinking in sixteenth-century China.

LSYC, 1959 (no. 10), 39. 


\section{Lu Gwei-Djen and Joseph Needham}

Hu Tao-Ching (l)

'Mêng Chhi Pi Than' Chiao Chêng.

Complete Annotated and Collected Edition of the Dream Pool Essays (of Shen Kua, AD 1086). 2 vols.

Shanghai Publishing Co., Shanghai, 1956.

Analytical rev. Nguyen Tran-Huan, Revue d'Histoire des Religions (Annales du Musée Guimet, Paris).

Huang Shêng-Chang (l)

Yün-Mêng Chhin Chien Pien Chêng.

A New Interpretation of the Inscribed Bamboo Slips of the Chhin period discovered at Yün-mêng (in Hupei).

Chinese J. Archaeol., 1979 (no. 1), 1 (esp. p. 4).

Hsü Lien (I)

'Hsi Yüan Lu' Hsiang I.

Detailed Discussion of the 'Washing away of Unjust Imputations, or Wrongs'.

Peking, 1854.

Jen An (I)

Chung-Kuo Ku-Tai I-Hsüeh Chia.

Chinese Physicians of Ancient and Medieval Times.

Shanghai Shu Chü, Hongkong, 1963.

Kao Min (l)

Yün-Mêng Chhin Chien Chhu Than.

A Preliminary Discussion of the pre-Chhin Writing found at Yün-mêng.

Honan Jen-Min Chhu-Pan-Shê, 1979.

Kao Ming-Hsüan \& Sung Chih-Chhi (I)

Shih-Chieh Ti-I Pu Fa-I-Hsüeh Chuan Chu.

The First Book in the World on Legal Medicine (Sung Tzhu's Hsi Yuan Chi Lu of AD 1247).

In Anon. (202) q.v., p. 474.

Koseki Kuniyoshi (1)

Notes on the First Use of the Phrase 'hsoi gaku', meaning Forensic medicine.

Nihon Ishigaku Zasshi (Jap. J. Hist. Med.), 1985,31 , no. 4, p. 529.

Kuan Chhêng-Hsüeh (I)

Lun Sung Tzhu yü 'Hsi Yuan Chi Lu' Yen-Chiu Chung Shih Wu chi Yuan Yin.

A Discussion of Some Errors and their Causes in the Studies on Sung Tzhu and the 'Washing Away of Unjust Imputations, or Wrongs'

Chi-Lin Ta-Hsüeh Ku Chi Suo, 1985.

Kung Ko $(I)$

I Shih Chi Nien.

Chronological Index of Medical Affairs.

Chung-Kuo Kho Chi Shih Liao [Materials for the Study of the History of Science \& Technology in China], 1982, no. 1, 106.
Kuo Ching-Yuan (l) et al.

Shih Yung Fa-I-Hsüeh.

Practical Forensic Medicine.

Kho-Hsüeh Chhü Pan Shih, Shanghai, 1980.

Lan Ling (I)

Than Li-Shih-Shang ti Yuan An.

A Discussion on Erroneous Criminal Judgments in History.

Pai Kho Chih Shih (Peking), 1980, (no. 2), 24.

Li Thao (l)

Chung-Kuo Hsi-Chi chung ti I-Shêng.

Medical Doctors in Chinese Drama.

I Shih Tsa Chih [Chinese Med. Hist. J.], 1948, 1 (nos. 3, 4), 1.

Lu Hsin-Yuan (I)

Sung Shih I.

Additions (lit. 'Wings') to the 'History of the Sung Dynasty'.

Chhing, c. 1880.

Miyashito Saburo (4)

Sö-gen no Iriyō

Medical Therapy in the Sung and Yuan periods.

In Yabuuchi Kiyoshi (26) q.v., p. 123.

Phang Huai-Chhing, Chen Fêng, Chung Ju \& Chih $\mathrm{Ju}(1)$

Shenhsi Shêng Chhi-shan-hsien Tung Chia Chhun Hsi Chou Thung-Chhi Chiao-hsüeh Fa-Chüeh Chien-Pao.

A Report on the Excavation of a Pit of Western Chou Bronze Ware at Tung Chia Chhun, Chhishan hsien, Shensi Province.

Wên $W u$ [History and Archaeology], 1976, (no. 5), 26.

Phang Pho (I)

Chhi-shih Nien Tai chhu thu Wên-Wu-ti ssuhsiang Shih ho Kho-Hsüeh Shih II.

The Meaning of the Archaeological Discoveries of the Seventies for the History of Thought and the History of Science.

Wên $W u, 1981$, no. 5 (no. 300), 59.

Shangkuan Liang-Fu (I)

Chung-Kuo I Yao Fa Chan Shih.

The Development of Medicine and Pharmacy in Chinese Culture (a series of 104 biographies).

Hsin-Li, Hongkong, 1974.

Shêng Chang ( $I$ )

Chhi-Shan Hsin Chhu Chen Yi Jo Kan Wên Thi Than-So.

A study of Certain Problems connected with the newly excavated bowl-shaped Ladle with Spout from ChhiShan bearing the name of the official Chen.

$W e ̂ n ~ W u, 1976$, no. 6, 40. 


\section{A history of forensic medicine in China}

Shih Jo-Lin (I)

Chung-Kuo Ku-Tai-ti I-Hsüeh Chia.

Biographies of Ancient and Medieval Chinese Medical Experts.

Kho-Hsüeh Chi-Shu, Shanghai, 1959.

Sung Ta-Jen (8)

Wei Ta Fa-I Hsüeh Chia, Sung Tzhu Chuan Lüeh.

A Biography of the Great Medico-Legal Expert, Sung Tzhu.

I Hsüeh Shih . . . [J. Hist. Med .. .], 1957, no. 2, 116 (I Shih Tsa Chih, 1957, 8, 116).

Sung Ta-Jen (9)

Chung-Kuo Fa-I Tien Chi Pan Pên Khao.

A Study of the Different Editions of Chinese Books on Forensic Medicine.

I Hsüeh Shih . . . [J. Hist. Med . . .], 1957, no. 4, 278 (I Shih Tsa Chih [Chinese Med. Hist. Journ.]).

Thang Lan (4)

Shen-hsi Shêng Chhi-Shan Hsien Tung-Chiatshun Hsin Chhu Hsi Chou Chung-Yao Thung-Chhi Ming Tzhu ti I Wên ho Chu Shih.

A Transcription of the Inscriptions on Western Chou Bronzes unearthed from Tung-chia Village near Chhi-shan in Shensi. Wên $W u, 1976$, no. 5, 55.

Thang Lan (5)

Yung Chhing Thung Chhi Ming Wên Lai YenChu Hsi Chou Shih, etc.

A Study of Western (Early) Chou History in the Light of the Bronze Inscriptions; the Great Value of the Bronzes discovered in Recent Years at Paochi.

Wên $W u, 1976$, no. 6, 31 .

Thung Lien (I)

Pu Chu 'Hsi Yuan Lu' Chi Chêng.

Revised Annotations on the Collected Commentaries of the "Washing Away of Unjust Imputations, or Wrongs'.

Peking, 1843.

Wang Chiu-Kuang (3)

Kuan-yü Hung Kuang Yen Shih.

On the Use of Red Light for Examining Corpses.

Hang-chou Ta-Hsüeh Hsüeh Pao [Hangchow University J.], 1984, 11 (no. 3), 328.
Wang Yu-Huai (1)

Pu Chu 'Hsi Yuan Lu Chi-Chêng'.

Annotated 'Hsi Yuan Lu Chi-Chêng'.

[Incorporating eleven books in all: $H Y L P u-I$

(1733); HYL Pei-Kao (1777), HYL Pien-

Chêng (1838), HYL Chieh (1831), Chien-Yen

Cha-Shuo, Chien-Yen Cha-Shuo Ko, Pao Chien Phien, Chiu Chi Fang, Shih Hsiang Pi Lu (1836), Chien-Yen Ho Chhan (1836), Hsing-Pu Thi-Ting Chien Ku Tu Ko (1770).]. 6 chapters in 5 vols., 1843 (prefaced 1796).

Yabuuchi Kiyoshi (26) (ed.)

Sögen Jidai no Kagaku Gijutsushi.

(Essays) on the History of Science and Technology in the Sung and Yuan Periods. Jinbun Kegaku Kenkyusō, Kyoto, 1967; repr. 1970.

Yang Fêng-Khun (I)

'Hsi Yüan Chi Lu' Chiao I.

Collated Version of the Hsi Yüan Chi Lu by Sung Tzhu (AD 1308 edition).

Chhün-chung, Peking, 1980.

Yang Wên-Ju \& Li Pao-Hua (I)

Chung-Kuo Li-Tai Ming I Phing Chieh.

Evaluations of the Work of the Famous Chinese Physicians.

Shen-Si Kho-Hsüeh Chi-Shu, Sian, 1980.

Yao Tê-Yü (I)

'Hsi Yuan Lu' Chieh

Analysis of the 'Washing Away of Wrongs'.

Peking, 1831.

Yeh Yü-Phing (1)

Tso Li Yao Yen

Important Advice to Government Officials.

Peking, 1843.

Yüan Chhi-Hsin (l)

Pu Chin 'Hsi Yuan Lu' Chi Chêng.

Revised Annotations on the Collected Commentaries of the 'Washing Away of Unjust Imputations, or Wrongs'.

Peking, 1832. 


\section{LIST OF WESTERN REFERENCES}

ACKerkneCht, E. H. (2). 'The Early History of Legal Medicine'. Ciba Symposium, 1950-1, 11, 128.

Alabaster, E. (1). Notes and Commentaries on Chinese Criminal Law and cognate Topics, with special attention to ruling Cases; together with a brief Excursus on the Law of Property; chiefly founded on the Writings of the late Sir Chaloner Alabaster, KCMG, sometime HBM Consul-General in China. Luzac, London, 1899.

Amundsen, D. W. \& Ferngren, G. B. (1). 'The Forensic Role of Physicians in Ptolemaic and Roman Egypt'. Bull. Hist. Med., 1978, 52 (no. 3), 336.

Balazs, E. (9). 'L'Histoire comme Guide de la Pratique Bureaucratique; les Monographies, les Encylopédies, les Recueils de Statuts', in Beasley \& Pulleyblank (1), q.v., p. 78.

Balazs, E. \& Hervouet, Y. (1). A Sung Bibliography. Chinese University Press, Hongkong, 1978.

Beasley, W. G. \& Pulleyblank, E. G. (1) (ed.). Historians of China and Japan. Oxford University Press, London, 1961. (Historical Writing on the Peoples of Asia, Far East Seminar; Study Conference of the London School of Oriental Studies, 1956).

Beck, Theodore R. (1). Elements of Medical Jurisprudence. Webster \& Steinneis, Albany, N.Y., 1823.

De Blegny, Nicolas (1). La Doctrine des Rapports de Chirurgie; fondée sur les Maximes d'usage et sur la Disposition des nouvelles Ordonnances. Lyons, 1684. Eng. tr. Amaubry, London, 1684.

Bodde, D. (26). 'Authority and Law in Ancient China'. In Authority and law in the Ancient Orient, p. 41 (Supplement no. 17 to J. Am. Oriental Soc., 1954).

BodDE, D. (28). 'Forensic Medicine in Pre-Imperial China'. J.Am. Oriental Soc., 1982, 102, 1-15.

BodDE, D. (29). 'Basic Concepts of Chinese Law; the Genesis and Evolution of Legal Thought in Traditional China'. Proc. Am. Philosophical Soc., 1963, 107, 375.

Bodde, D. \& Morris, C. (1). Law in Imperial China. Harvard Univ. Press, Cambridge, Mass., 1967; rev. Hsü Tao-Lin, Ching-Hua Hsüeh Pao (Taiwan) [Ching-Hua University J. Chinese Stud.], 1969, 476.

BreITENSTEIN, H. (1). Gerichtliche Medizin der Chinesen von Wang-in-Hoai nach dem Holländischen Übersetzung F. M. de Grijs. Grieben (Furnau), Leipzig, 1908.

Camps, F. E. \& Cameron, J. F. (1). Practical Forensic Medicine. Hutchinson, London, 1971. Based on a previous text by F. E. Camps \& W. B. Purchase (1956).

Camston, C. (1). 'Remarks on the History of Forensic Medicine, from the Renaissance to the Nineteenth Century'. Medical Record (New York), 1910, no. 22, 707.

Cassar, Paul (1). 'A Medico-Legal Report of the Sixteenth Century from Malta'. Med. Hist., 1974, 18 (no. 4), 354.

à Castro, Rodericus (1). Medicus Politicus. Hamburg, 1614.

CCHÜ Thung-Tsu (1). Law and Society in Traditional China. Mouton, The Hague, 1961. (Le Monde d'Outre-Mer, 1st ser., no. 4).

Chamfrault, A. \& Ung Kang-Sam (1). Traité de Médecine chinoise; $d$ ' apres les Textes chinois anciens et modernes, 5 vols. Coquemard, Angoulême, 1954.

[Ciвor, P. M.] (8). 'Notice du livre Chinois Si Yuen [the Hsi Yuan Lu]'. Mémoires concernant l'Histoire, les Sciences, les Arts, les Moeurs et les Usages des Chinois, 1779, 4, 421. 


\section{A history of forensic medicine in China}

Codronchi, Battista (1). De Morbis Veneficis. Venice, 1595.

Couvreur, F. S. (3) (tr.). 'Li Ki' [Li Chi], ou Mémoires sur les Bienséances et les Cérémonies, 2 vols. Hochienfu, 1913.

CREEL, H. G. (9). The Origins of Statecraft in China. Vol. 1, The Western Chou Empire. University of Chicago Press, 1970.

Devaux, Jean (1). L'Art de Faire les Rapports en Chirurgie, etc. Paris, 1693; 2nd ed. Paris, 1703.

Doe, Janet (1). A Bibliography, 1545 to 1940, of the Works of Ambroise Paré (1510 to 1590), Premier Chirurgien et Conseiller de Roi, etc. Van Heusden, Amsterdam, 1937 (History of Medicine series, no. 4).

Escarra, Jean (1). (a) Le Droit Chinois. Vetch, Peking, 1936; Sirey, Paris, 1936.

(b) 'La Conception Chinoise de Droit'. Archs de la Philos. du Droit et de la Sociol. juridique, 1935, 5, 7 [identical with the earlier part of the book].

(c) 'Chinese Law', in Encyclopaedia of the Social Sciences, ed. R. A. Seligman, 15 vols. Macmillan, London, 1930-35, vol. 9, 249.

Fedele, Fortunato (1). De Relationibus Medicorum, Libri Quatuor. Palermo, 1602; repr. Leipzig, 1674.

FÊNG YU-LAN (5) (tr.). Chuang Tzu; a new selected translation with an exposition of the philosophy of Kuo Hsiang, Commercial Press, Shanghai, 1933.

FISCHER-HOMBERGER, E. (1). Medizin vor Gericht; Gerichtsmedizin von der Renaissance bis zur Aufklärung. (With 70 illustrative case examples contributed by C. Ernst). Huber, Bern, Stuttgart and Vienna, 1983.

Forrest, Richard D. (1). 'The Early History of Wound Treatment'. J. R. Soc. Med., 1982, 75 (no. 3), 198.

Franke, H. (19) (ed.). Sung Biographies, 3 vols. Steiner, Wiesbaden, 1976. (Münchener Ostasiatische Studien, no. 16 pts. 1, 2, and 3).

Giles, H. A. (7) (tr.). 'The Hsi Yüan Lu or "Instructions to Coroners" ' [translated from the Chinese]. Proc. roy. Soc. Med., 1924, 17, 59-107. First published in China Review, 1874, 3, 30, 92, 159, etc.

Gordon, I. \& Shapiro, H. A. (1). Forensic Medicine; a Guide to Principles. Churchill Livingstone, Edinburgh, etc., 1975.

GoRsky, J. A. 'The History of Forensic Medicine'. Charing Cross Hospital Gazette 1960, 58, 31.

Gradwohl, R. B. H. (1) (ed.) Legal Medicine. Mosby, St. Louis, Missouri, 1954; 2nd ed. F. E. Camps (ed.), London, 1968; 3rd ed. F. E. Camps, A. E. Robinson \& B. G. B. Lucas (eds.), Bristol, 1976.

GrEenE, L. B. (1). 'Frontiers of Medical Jurisprudence; a Historical Background'. Connecticut Medicine, $1962,26,1$.

GreEnWoOd, William (1). Buleuterion, or, a Practical Demonstration of County Judicatures. Place, London, 1664.

DE GRIJs, C. F. M. (1). Geregtëlÿke Geneesskunde, mit het Chinees vertaald. 1863. A Dutch translation of Sung Tzhu's $\mathrm{Hsi}$ Yuan $\mathrm{Lu}$, or rather, a later version of it.

van Gulik, R. H. (6) (ed. and tr.). 'Thang Yin Pi Shih', Parallel Cases from under the Pear-Tree; a 13th-century Manual of Jurisprudence and Detection. Brill, Leiden, 1956. (Sinica Leidensia, no. 10.)

GweE, A. L. (1). 'History of Medical Ethics in China'. in Karplus (1), q.v., p. 11.

Harper, Donald J. (3). 'Transciptions of the Chhin Bamboo Slips on Criminal Law'. Early China, 1977, 3, 103. Review of Anon. (260) with translations. 


\section{Lu Gwei-Djen and Joseph Needham}

HaRT, H. L. A. (1) The Concept of Law. Oxford, 1961.

Haskins, C. H. (3). 'England and Sicily in the Twelfth Century'. Engl. hist. Rev., 1911, 26 (no. 103), 433; (no. 104), 641.

Hill, W. G., Jeffreys, A. J., Brookfield, J. F. Y. \& Semeonoff, R. (1). 'DNA Fingerprint Analysis in Immigration Test-Cases'. Nature, 1986, 322, 290.

Holzman, D. (1). 'Shen Kua and his Mêng Chhi Pi Than'. T'oung Pao, 1958, 46, 260.

HüвотTER, F. (1). Die chinesische Medizin zu Beginn des XX Jahrhunderts, und ihr historische Entwicklungsgang. Schindler, Leipzig, 1929 (China-Bibliothek d. Asia Major, no. 1).

Hulsewé, A. F. P. (1). Remnants of Han Law. Brill, Leiden, 1955 [photolitho typescript, including translations of Chhien Han Shu, Chs. 22 (first part) \& 23,] (Sinica Leidensia, no. 9).

HulsewE, A. F. P. (4). 'The Chhin Documents Discovered in Hupei in 1975'. T'oung Pao, 1978, 64 (no. 4), 175, 338.

Hulsewt, A. F. P. (6). Remnants of Chhin Law; an Annotated Translation of the Chhin Legal and Administrative Rules of the 3rd Century BC, discovered in Yün-mêng Prefecture, Hupei Province, in 1975. Brill, Leiden, 1985. (Sinica Leidensia, no. 17).

Hunnisetr, R. F. (1). The Mediaeval Coroner. Cambridge University Press, 1961.

HunNiSETt, R. F. (2) 'The Origins of the Office of Coroner'. Trans. roy. hist. Soc., 1958 (5th Ser.), 8, 85.

JefFreys, A. J., Brookfield, J. F. Y. \& Semeonoff, R. (1). 'Positive Identification of an Immigration Test-Case using Human DNA Fingerprints'. Nature, 1985, 317, 818.

KARPLUS, H. (1), (ed.). International Symposium on Society, Medicine and Law (Jerusalem, 1972). Elsevier, Amsterdam, 1973.

Kellaway, W. (1). 'The Coroner in Mediaeval London', in Kellaway (2), q.v., p. 75.

Kellaway, W. (2). Studies in London History. Hodder \& Stoughton, London, 1969.

KERR, D. J. A. (1). Forensic Medicine. 6th ed. Black, London, 1956.

Keyfetz, Nathan (1). 'The Population of China'. Scientific American, 1984, 250 (no. 2 ), 22.

Kristeller, Paul (1). Studies in Renaissance Thought and Letters. Ed. Storia e Lett., Rome, 1969.

Ku Hung-Ming (1) (tr.). The Discourses and Sayings of Confucius. Kelly and Walsh, Shanghai, 1898.

KUnST, R. A. (1). 'More on hsiu and wu hsing, with an Addendum on the Use of Archaic Reconstructions'. Early China, 1977, No. 3, 67. With a reply by John S. Major, p. 69.

Legge, J. (2)(tr.). The Chinese Classics, etc. Vol. 1., Confucian Analects, The Great Learning, and the Doctrine of the Mean. Legge, Hongkong; Trübner, London, 1861. Photolitho re-issue, Hongkong University Press, 1960, with supplementary volume of concordance tables, etc.

Legge, J. (5) (tr.) The Sacred Books of China. The Texts of Taoism, 2 vols. Clarendon Press, Oxford, 1891. Photolitho reprint, 1927 (SBE nos. 39 and 40).

Legge, J. (7) (tr.). The Sacred Books of China. The Texts of Confucianism, Pt. 3, the Li Ki (Li Chi). 2 vols. Clarendon Press, Oxford, 1885. Reprint, 1926 (SBE, nos. 27 and 28).

Liebermann, F. (1). Die Gesetz der Angelsachsen. Scientia, Aalen, 1960. 


\section{$A$ history of forensic medicine in China}

LIN Yü-Thang (1) (tr.). The Wisdom of Lao Tzu [and Chuang Tzu], translated, edited, and with an introduction and notes. Random House, New York, 1948.

Litolf, C. H. (1) (tr.). 'Le Livre de la Réparation des Torts (Hsi Yuan Lu); Constatations Légales dans les Cas de Crimes contre les Personnes en vue de la Réparation du Préjudice Causé'. Revue Indochinoise, $1909,531,676,765,881,1017,1107,1217 ; 1910,418$. Translation from a Vietnamese version. Separate publication: Imprimerie de l'Extrême Orient, Hanoi, 1910.

LoEwe, M. (4). Records of Han Administration. 2 vols. Cambridge University Press, 1967. (University of Cambridge Oriental Publications no. 11.).

Lorion, L. (1). Criminalité et Médécine Judiciaire en Cochinchine. Storch, Lyon, 1888.

Lu Gwei-Djen \& Needham, Joseph (2). 'China and the Origin of (Qualifying) Examinations in Medicine'. Proc. roy. Soc. Med., 1963, 56, 63.

Lu Gwei-Djen \& Needham, Joseph (4). 'Records of Diseases in Ancient China'. In Diseases in Antiquity (ch. 17), ed. D. Brothwell \& A. T. Sandison Thomas, Springfield, Illinois, 1967, p. 222. Repr. Am. J. Chinese Med., 1976, 4 (no. 1), 3.

Lu Gwei-Djen \& NeEdham, JosePh (5). Celestial Lancets; a History and Rationale of Acupuncture and Moxa. Cambridge University Press, 1980.

Lyall, L. A. (23) (tr.). The Sayings of Confucius [Lun Yü]. Longmans Green, London, 1935. This edition supersedes earlier editions.

McKnight, B. E. (1). The Washing Away of Wrongs (a translation of Sung Tzhu's Hsi Yuan Chi Lu). University of Michigan Press, Ann Arbor, Mich., 1981. (Science, Medicine \& Technology in East Asia series, no. 1.).

McKnight, B. E. (2). The Quality of Mercy; Amnesties and Traditional Chinese Justice. Hawaii University Press, Honolulu, 1981. Rev. P. Baker, J. Asiatic Soc., 1983 (no. 1), 158.

MCLeod, Katrina C. D. \& Yates, Robin D. S. (1). 'Forms of Chhin Law; and Annotated Translation of the Fêng Chen Shih [Forms for Sealing and Guarding, or, Patterns]'. Harvard J. Asiatic Stud., 1981, 41, 111-163.

MARtin, Ernest (1). Recueil des Procedés au Moyen desquels on lave quelq'un d'une Injure [the Hsi Yuan Lu]. Leroux, Paris, 1886.

Miyashita SAburó (1). "Sung Tzhu” (biography) in Franke (19), q.v., vol. 3, p. 990.

Monro, C. H. (1) (tr.). The Digest of Justinian. Cambridge University Press, 1904.

Munster, L. (1). 'La Medicina Legale a Bologna nel Quattrocento'. Actes du VIII Congrès Internationale d'Histoire des Sciences. Florence, 1956, p. 687.

Needham, Joseph (56). Time and Eastern Man. (Henry Myers Lecture, Royal Anthropological Institute, 1964). Royal Anthropological Institute, London, 1965.

NeEDHAM, JoSEPH (64). Clerks and Craftsmen in China and the West: Lectures and Addresses on the History of Science and Technology. Cambridge University Press, 1970.

NeEdham, JosePh (89). 'Science, Technology, Progress and the Breakthrough; China as a Case Study in Human History'. Lecture given at the Nobel Conference, Stockholm, Royal Swedish Academy, August 1983.

Needham, Joseph \& Liao Hung-Yung (1). 'The Ballad of Mêng Chiang Nü weeping at the Great Wall'. Sinologica, 1948, 1, 194. 


\section{Lu Gwei-Djen and Joseph Needham}

Needham, Joseph \& Lu Gwei-Djen (8). 'Medicine and culture in China'. In Medicine and culture: proceedings of a historical symposium organized jointly by the Wellcome Institute of the History of Medicine, London, and the Wenner-Gren Foundation for Anthropological Research, New York, ed. F. N. L. Poynter. Wellcome Institute, London, 1969. Repr. in Needham (64), q.v., p. 263.

O’Malley, C. D. (2) Andreas Vesalius of Brussels. University of California Press, Berkeley, Calif., 1964.

O’Neill, Y. V. (1). 'Pope Innocent III and the Evolution of Anatomy'. Med. Hist., 1976, 20 (no. 4), 429.

O’Neill, Y. V. \& Chan, G. F. (1). ‘A Chinese Coroner's Manual and the Evolution of Anatomy'. J. Hist. Med., 1976, 31 (no. 1), 3.

Paré Ambroise (1). 'Traicté des Rapports, et du Moyen d'embaumer les Corps Morts', pp. 931-45 of Les Oeuvres de M. Ambroise Paré, Conseiller et Premier Chirurgien du Roy, etc. Buon, Paris, 1575; repr. 1579, 1585; Latin ed. 1582; English ed. 1634 contains 'How to make Reports, and to Embalme the Dead', Bk. XXVIII, pp. 680 ff. Cf. Doe (1), q.v., p. 107.

Pelliot, P. 'Notes de Bibliographie Chinoise. II. Le Droit Chinois’. Bull. Éc. fr. d'extréme Orient, 1909, 9, 123.

Pothier, R. J. \& De Bréard-Neuville, M. (1). Pandectes de Justinien, mises dans un nouvel Ordre; avec les Lois du Code et les Nouvelles qui confirment, expliquent ou abrogent le Droit des Pandectes. 25 vols. Dondy-Dupré, Paris, 1818.

Pulleyblank, E. G. (7). 'Chinese Historical Criticism; Liu Chih-Chi and Ssuma Kuang', in Beasley \& Pulleyblank (1), q.v., p. 135.

Samoggia, L. (1). 'I Medici della Famiglia Zancari all'initio dell Secolo XIV in Bologna'. Boll. Sci. med., 1964.

Scotr, S. P. (1). The Civil Law; including the Twelve Tables, the Institutes of Gaius, the Rules of Ulpian, the Opinions of Paulus, the Enactments of Justinian and the Constitutions of Leo-translated from the original Latin, edited, and compared with all accessible Systems of Jurisprudence Ancient and Modern. 17 vols. Central Trust Co., Cincinnati, 1932.

Simili, Alessandro (1). 'Tre Caratteristiche Inquisizioni a Bologna nel Secolo 14'. Episteme, 1969, 3 (no. 2), 115.

Simili, Alessandro (2). 'The Beginnings of Forensic Medicine in Bologna', in Karplus (1), q.v., p. 91.

Simili, Alessandro (3). Storia della Medicina Legale. Episteme monograph series, Milan, 1974.

SINGER, C. (25). A Short History of Anatomy and Physiology from the Greeks to Harvey. Dover, New York, 1957. Revised from The Evolution of Anatomy, Kegan Paul, French \& Trubner, London, 1925.

Smith, Sydney (1). 'The History and Development of Forensic Medicine'. Br. med. J., 1951, i, 599.

VAN DER SPRENKel, S. (1). Legal Institutions in Manchu China. Athlone, London, 1962; repr. 1966, 1971; 2nd ed. 1977. (London School of Economics Monographs on Social Anthropology, no. 24).

ThомаS, J. A. C. (1). The Institutes of Justinian; Text, Translation and Commentary. North Holland Publishing Co., Amsterdam, 1975.

Thомas, J. A. C. (2). Textbook of Roman Law. North Holland Publishing Co., Amsterdam, 1976.

Tissot, P. A. (1) (tr.). Code et Novelles de Justinien; Novelles de l'empereur Léon; et Fragments de Gaius, d'Ulpian et de Paul, etc. Behmer, Metz, 1806; and Rondonneau, Paris, 1806.

Veith, I. (1) (tr.). 'Huang Ti Nei Ching Su Wên'; The Yellow Emperor's Classic of Internal Medicine, Chs. 1-34, translated from the Chinese, with an Introductory Study. Williams \& Wilkins, Baltimore, 1949. 


\section{A history of forensic medicine in China}

Vesalius, Andreas (1). De Fabrica Humani Corporis. 1543.

Volk, Peter \& Warlo, H. J. (1). 'The Role of Medical Experts in Court Proceedings in the Mediaeval Town', Karplus (1), q.v., p. 101.

Waley, A. (5) (tr.). The Analects of Confucius. Allen \& Unwin, London, 1938.

Walls, H. J. (1). Forensic Science; An Introduction to Scientific Crime Detection. 2nd ed., Sweet \& Maxwell, London, 1974.

Walters, THE ReV. RichaRd (1). Lord Anson's Voyage round the World, 1740 to 1744. 3 vols. London, 1750.

Wilhelm, Helmut (17). 'Notes on some Sung shih-hua (discourses on poetry)'. In Sung Studies, in memoriam Étienne Balazs; Ser. II, Civilisation, no. 3, Hautes Études, Paris, 1984, pp. 267-330.

Wilhelm, Richard (3) (tr.). Frühling u. Herbst d. Lü Bu-We (the Lü Shih Chhun Chhin). Diederichs, Jena, 1928.

Wilhelm, Richard (6) (tr.). 'Li Gi', das Buch des Sitte des älterten und jungeren Dai, Diederichs, Jena, 1930.

Wilkinson, John (1). A Treatise collected out of the Statutes of this Kingdom. London, 1657.

YANG LIEN-SHÊNG (10). 'The Organisation of Chinese Official Historiography; Principles and Methods of the Standard Histories from the Thang through the Ming', in Beasley \& Pulleyblank (1), q.v., p. 44.

Zacchia, Paolo (1). Quaestiones Medico-Legales. Rome, 1621-35. 
1 洗冤集錄

2 宋慈

3 醀和

4 龇緩

5 扁鵲

6 淳于意

7 仵作

8 坐婆

9 為人子者不可不知嚙

10 皇甫䍀

11 針尒甲乙經

12 榣婆

13 隶豆妾

14 狄仁集

15 包拯

16 吴稚

17 朱喜

18 真德秀

19 進士

20 主簿

21 信整

22 南创

23 提䓡刑獄

24 常州

25 史能之

26 知常州軍州事

27 重修思陵志

28 昌成村

29 建陽憬

30 初情

31 佐理

32 通著

33 更胥

34 甘詰

35 虚被澇漉

36 内怒錄
37 氣

38 血

39 脉絡

40 表裡

41 慎刑說

42 未信篇

43 結案式

44 折獄医鑑

45 鄭克

46 和凝

47 和㠓

48 疑熇集

49 疑憱前集

50 疑狺後集

51 徐之才

52 明冤窝論

53 趙時棠

54 桂蕾榮

55 棠陰比事

56 司理參軍

57 張舉

58 許元

59 睡虎地

60 雲萝

61 封診式

62 喜

63 犋死

64 田舍

65 庭

66 㠅

67 經死

68 令史

69 出子

70 隸妾

71 孺

72 癞 


\section{A history of forensic medicine in China}

73 黄帝内經素問

74 属

75 㾖所

76 癗遷所

77 惡疾

78 法家

79 儒家

80 劉放

81 蘇軾

82 月令

83 吕氏春秋

84 䄚記

85 小戴

86 孟秋之月

87 傷

88 創

89 折

90 斷

91 蔡佂

92 王燭察典

93 張虔

94 月令解

95 岐山

96 医

97 佣匜銘文

98 白揚父

99 牧牛

100 上司

101 俱

102 黝刑

103 未罚金

104 鞭

105 鍰

106 鼎

107 旂

108 白楚父
109 两

110 斤

111 趙逸齎

112 平冤錄

113 王與

114 無冤錄

115 宋元檢驗三錄

116 新注無冤錄

117 柳義孫

118 河合甚兵衛

119 無冤錄述

120 孫星衍

121 張景

122 補疑淤集

123 大明律刑書據會

124 大明律例致君奇術

125 律例館校正洗冕録

126 检骨圆格

127 洗冤錄集證

128 王又槐

129 阮其新

130 張錫番

131 童廉

132 洗冤錄詳義

133 許楗

134 補註洗冤錄集證

135 重刊補注洗冤錄集證

136 骨骼学

137 畫匠

138 洗冤錄簙釋

139 王肯堂

140 洗冤錄辩正

141 籰中溶

142 保㙜

143 守市

144 磁綮配律 


\section{Lu Gwei-Djen and Joseph Needham}

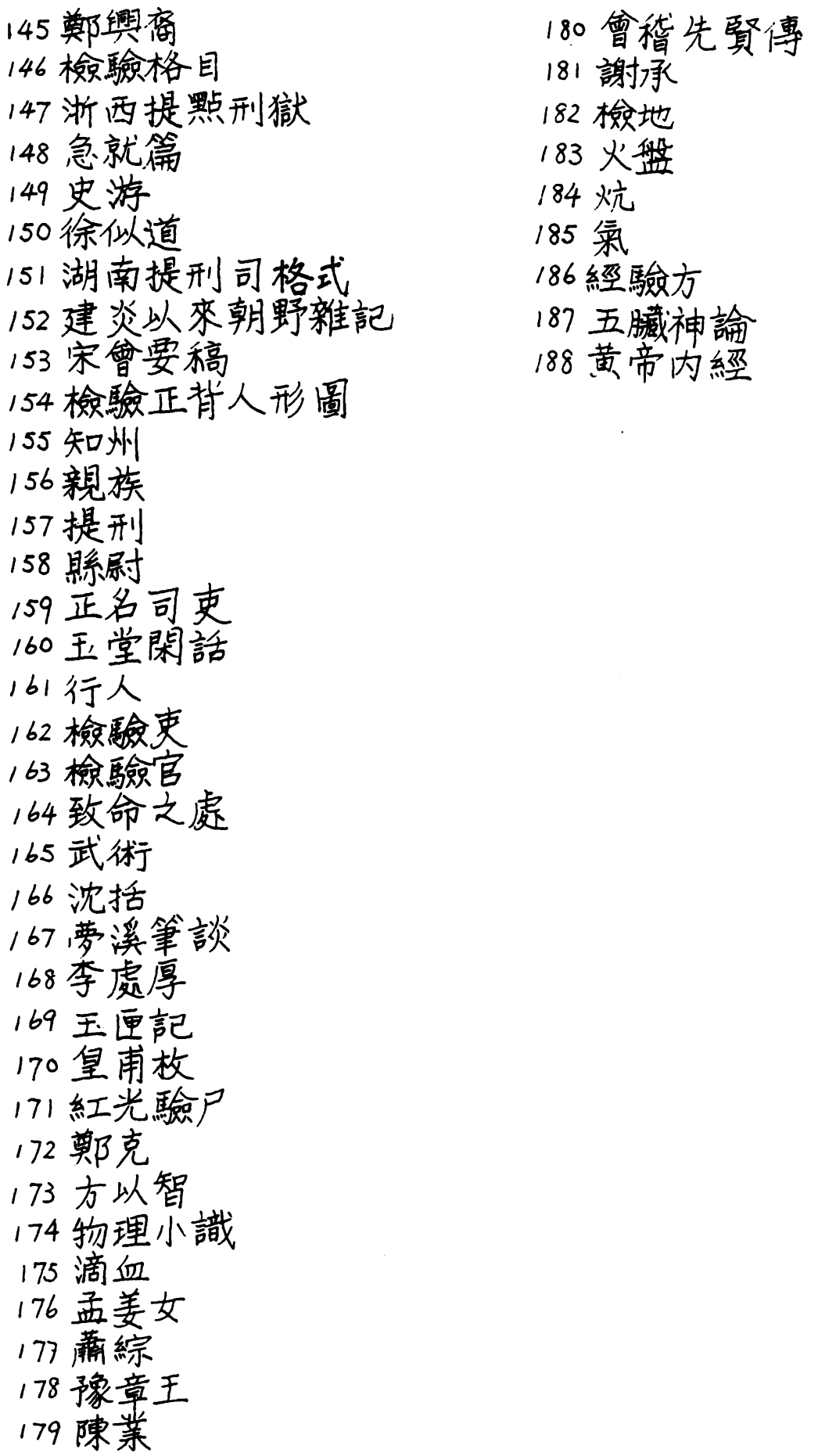

